Canadian Journal of Applied Linguistics

\title{
Fee-Paying English Language Learners: Situating International Students' Impact on British Columbia's Public Schools
}

\section{Ryan Deschambault}

Volume 21, numéro 2, 2018

URI : https://id.erudit.org/iderudit/1057965ar

DOI : https://doi.org/10.7202/1057965ar

\section{Aller au sommaire du numéro}

\section{Éditeur(s)}

University of New Brunswick

\section{ISSN}

1920-1818 (numérique)

Découvrir la revue

\section{Citer cet article}

Deschambault, R. (2018). Fee-Paying English Language Learners: Situating International Students' Impact on British Columbia's Public Schools. Canadian Journal of Applied Linguistics / Revue canadienne de linguistique appliquée, 21(2), 46-79. https://doi.org/10.7202/1057965ar

\section{Résumé de l'article}

Cet article examine la relation entre l'éducation internationale et l'éducation en anglais langue additionnelle (ALA) dans le système scolaire public de la Colombie-Britannique. En m’appuyant sur un large éventail de données générées dans le cadre d'une étude longitudinale auprès d'élèves internationaux payant des frais (EPF) dans un district scolaire urbain de la Colombie-Britannique, je démontre que le recrutement des EPF et leur présence ont une incidence sur la socialisation dans les écoles publiques de la province. Contrairement à la façon dont on tient compte des EPF dans les statistiques officielles du gouvernement, j'illustre comment, entre plusieurs intervenants et dimensions du système public, les EPF sont traités et représentés de façon routinière comme des apprenants de langue anglaise. J'avance que ces construits routiniers sont des preuves d'une socialisation à plusieurs couches de l'éducation en ALA dans les efforts d'internationalisation du secteur M-12 de la Colombie-Britannique. J'explique certaines façons dont cette socialisation des EPF a des incidences sur l'apprentissage et

l'enseignement de l'ALA dans les écoles secondaires publiques. Je situe ma discussion de la relation entre les EPF et l'ALA dans le contexte plus large de la linguistique appliquée et les domaines de recherche en éducation liés à l'internationalisation et à la migration éducative dans les environnements scolaires de M-12. Je soulève des questions par rapport à la pertinence de la socialisation des EPF dans les discussions au sujet de l'éducation publique. 


\title{
Fee-Paying English Language Learners: Situating International Students' Impact on British Columbia's Public Schools
}

\author{
Ryan Deschambault \\ University of British Columbia
}

\begin{abstract}
This article examines the relationship between international education and English as an additional language (EAL) education in British Columbia's public education system. Drawing on a wide range of data generated as part of a longitudinal study of high school aged fee-paying international students (FISs) in an urban school district in British Columbia, I make the case that FIS recruitment and presence is having a socializing impact on EAL education in British Columbia's public schools. In contrast to the way FISs are accounted for in official government statistics, I show how, across multiple actors and dimensions of the public system, FISs are routinely treated and represented as English language learners (ELLs). I argue that these routinized constructions are evidence of the multilayered socialization of EAL education by internationalization efforts in British Columbia's K-12 sector, and discuss some of the ways this FIS socialization is consequential for EAL learning and teaching in public high schools. I situate my discussion of the FIS-EAL relationship within the larger context of applied linguistics and education-related research on internationalization and educational migration in K-12 settings, and raise questions about how FIS socialization is relevant to discussions of public education.
\end{abstract}

\section{Résumé}

Cet article examine la relation entre l'éducation internationale et l'éducation en anglais langue additionnelle (ALA) dans le système scolaire public de la Colombie-Britannique. En m'appuyant sur un large éventail de données générées dans le cadre d'une étude longitudinale auprès d'élèves internationaux payant des frais (EPF) dans un district scolaire urbain de la Colombie-Britannique, je démontre que le recrutement des EPF et leur présence ont une incidence sur la socialisation dans les écoles publiques de la province. Contrairement à la façon dont on tient compte des EPF dans les statistiques officielles du gouvernement, j'illustre comment, entre plusieurs intervenants et dimensions du système public, les EPF sont traités et représentés de façon routinière comme des apprenants de langue anglaise. J'avance que ces construits routiniers sont des preuves d'une socialisation à plusieurs couches de l'éducation en ALA dans les efforts d'internationalisation du secteur M-12 de la Colombie-Britannique. J'explique certaines façons dont cette socialisation des EPF a des incidences sur l'apprentissage et l'enseignement de l'ALA dans les écoles secondaires publiques. Je situe ma discussion de la relation entre les EPF et l'ALA dans le contexte plus large de la linguistique appliquée et les domaines de recherche en éducation liés à l'internationalisation et à la migration éducative dans les environnements scolaires de M-12. Je soulève des questions par rapport à la pertinence de la socialisation des EPF dans les discussions au sujet de l'éducation publique. 


\section{Fee-Paying English Language Learners: Situating International Students' Impact on British Columbia's Public Schools}

\section{Introduction}

While at the national level the largest percentage of international students attend tertiary-level institutions, in 2014 roughly 50,000 international students in Canada were studying at the elementary or secondary grade levels (Canadian Bureau for International Education, 2015). In British Columbia (BC), the province on which this article focuses, as of January 2017 there were 20,438 international students in K-12 education, 77\% $(15,870)$ of whom study in public schools (BC Ministry of Education [BCMoE], 2017). In educational policy and practice affecting K-12 contexts in $\mathrm{BC}$, the category "international student" is used to refer to students who "have moved from outside of Canada to British Columbia and do not meet the residency requirements of Section 82 of the School Act" (BCMoE, n.d.). Because of this, these students are charged yearly tuition fees to attend public schools (Study in BC, 2015). In the 2016/17 school year, 88\% $(13,923)$ of all such fee-paying international students (FISs) were enrolled in BC public secondary schools (Grades 8-12), with almost three quarters (72\%) in Grades 10, 11, and 12 (BCMoE, 2017).

Education policy encouraging the recruitment of FISs in BC has, since 2002, more than quadrupled FIS-based revenues - to roughly $\$ 242$ million in 2016/17 (Kuehn, 2018). In Vancouver, the efforts to recruit FISs to public schools over the last decade have coincided both with declining numbers of domestic enrolments and provincial cuts to education spending, and have been described by the director of the school district's International Education Program as "definitely subsidizing what is going on in public school districts" (Mitchell, 2004, para. 23). Policy researchers have pertinently framed the impact of FISs on BC's public education system in negative terms, with a dual critical focus on (a) neoliberal competition between school districts for FIS tuition monies, and (b) the educational inequities engendered by such competition (e.g., Fallon \& Poole, 2014; Kuehn 2002, 2012a, 2012b; Poole \& Fallon, 2015). However, these studies have overlooked a significant site of FIS impact: English as an additional language (EAL) education. And although some studies have mentioned links between FISs and EAL as part of larger discussions concerning students' individual experiences (Arnott 2012; Nelson, 2013), school-counselling support for FISs (Popadiuk \& Marshall 2011), and administrators' talk in the context of educational policy and finance (e.g., Fallon \& Paquette, 2009; Fallon \& Poole, 2014), to date there have been few (if any) studies that have treated connections between FISs and EAL education as a central focus. The findings reported in this article were thus guided by the following questions:

1. In what ways and to what effect are students, teachers, administrators and other stakeholders socialized to understand FISs as English language learners (ELLs)?

2. How is such FIS socialization used as a resource and by whom?

3. How does FIS socialization impact BC's education system?

I argue that FIS socialization has discursive and material impacts on the public education system. Emblematized in the routinized discursive construction of FISs as de facto ELLs, FIS socialization includes a palpable material impact on in student experience, classrooms, schools, and the public education system more generally. 
The remainder of the article is organized into eight sections. In the first section I give a brief overview of the current educational context in $\mathrm{BC}$, the policy environment from which this context emerged, and describe key differences between the FIS and ELL student categories. Then, after presenting a selective review of relevant research, I outline the conceptual frames for the article and provide a summary of the methodology and methods from which the article has been worked up. In the fifth and sixth sections I present analyses of a range of data (i.e., policy documents, student statistics, classroom demographics, interview accounts, and student work), and close the article with a discussion of the analyses and some concluding remarks.

\section{Background}

In the current the $\mathrm{K}-12$ educational context in $\mathrm{BC}$, there are documented trends of declining enrolment (e.g., BCMoE, 2016, 2017; British Columbia Teachers' Federation $[\mathrm{BCTF}], 2012$ ) and continued government underfunding of public education (e.g., Fallon \& Paquette, 2009; Fallon \& Poole, 2014; Kuehn, 2014). Indeed, White (2012) has argued that the "cumulative structural shortfalls school districts have struggled with in recent years ... have resulted in school closures, larger classes, and the loss of educational programs" ( $\mathrm{p}$. 2 ). School districts have thus been under increasing pressure to seek non-governmental sources of revenue via market-driven funding (e.g., Fallon \& Poole, 2014; Kuehn, 2002; Poole \& Fallon, 2015). For at least a decade, and increasingly given the lasting impact of FISs' tuition revenues for day to day operations, school districts have aggressively recruited FISs to fill empty spots in schools and offset continued cuts (e.g., Kuehn, 2007, 2014). In the 2016/17 school year, there were 15,870 FISs reported to be attending K-12 public schools (BCMoE, 2017), compared with 9,301 in 2010/11. With each FIS estimated to spend $\$ 24,500$ per year $(\$ 13,000-\$ 14,000$ on tuition; Kunin \& Associates, 2016; Study in $\mathrm{BC}, 2015)$, the BCTF has suggested that over 450 teachers in the K-12 public system are paid for by revenues collected from FIS tuition fees (Kuehn, 2014).

Beyond the impact these figures may suggest the FIS industry is having on K-12 public education in the province of $\mathrm{BC}$, the provincial government is currently engaged in a deliberate and concerted effort to position international education as playing a central role in the province's long-term economic health. ${ }^{1}$ Exemplary of this effort in $\mathrm{BC}$ are three government-funded reports which make specific reference to international education at the $\mathrm{K}-12$ level. The first is a report, commissioned in 2011 and updated regularly, on the economic contributions of international education to the province of BC (British Columbia Council for International Education [BCCIE], 2011, 2013, 2016, 2017; Kunin \& Associates, 2011, 2013, 2016, 2017). The report frames this economic impact in terms of FISs' "total spending," the sector's "direct contributions to provincial GDP," sectorspecific "jobs created," and "government revenue generated" (BCCIE, 2013, p.1; see also, e.g., Kunin \& Associates, 2013, 2016). The second document that foregrounds the importance of the K-12 international education sector to BC is Canada Starts Here: The BC Jobs Plan, in which international education is framed as both a means to recruit skilled immigrant workers and to assist with the delivery of quality education to BC students (Government of BC, 2012b; see also Extract 1 in this article). Finally, through what they have dubbed BC's International Education Strategy (Government of BC, 2012a), the government has set the ambitious goal to increase the number of international students "by 50 per cent over four years" (p. 13; i.e., by 2017). These documents, and the prominence 
they attribute to the role of international students in BC's economy, do little to address how FIS recruitment and presence is relevant to learners, teachers, or other stakeholders K-12 public education.

\section{Neoliberal Education Policy: Marketization and FISs}

Developed against the backdrop of what has been referred to as a neoliberal policy agenda (e.g., Fallon \& Pancucci, 2003; Fallon \& Paquette, 2009; Fallon \& Poole, 2014; Poole \& Fallon, 2015), in 2002 the government of BC implemented Bill 34-2002: The School Amendment Act (Bill 34, 2002). In addition to its goals of greater "fiscal \& academic accountability for public education," substantive reduction of the provincial deficit, "establishment of school councils," as well as via increases in "parental and student choices to attend any schools in [BC]" (Fallon \& Pancucci, 2003, p. 51), Bill 34's market ideological approach to public education imposed upon school districts the "flexibility" to find non-governmental (i.e., private) sources of revenue. In simple terms, two corollaries of being granted this flexibility were: (a) a decrease in government responsibility to fund public education; and (b) an increase in the competition between school districts for the students and funding they bring - essentially treating schools as providers of marketable commodities, and students and parents as consumers of educational services and products (see Fallon \& Pancucci, 2003, and Fallon \& Paquette, 2009, for fuller discussions of Bill 34; see also Fallon \& Poole, 2014, and Poole \& Fallon, 2015, for in-depth discussion of the current state of K-12 educational financing in $\mathrm{BC}$ ).

Although, as Poole and Fallon (2015) reported, many districts "have concentrated on low risk entrepreneurial initiatives" that include "selling advertising space on school property, renting space, selling course materials for online education, or providing educational or administrative consulting services" (p. 17), the most direct and fiscally advantageous source of non-governmental revenue has been the tuition monies paid by FISs (e.g., Kuehn, 2012a, 2014). But, although education policymakers, planners, and researchers have been quick to note and describe the general economic impact of FISs on BC's K-12 education system for better or worse, the impact - economic and otherwise - of FIS recruitment and presence on EAL education has received only superficial mention.

\section{FISs as Fee-Paying ELLs}

One potential reason so little attention has been given to the impact of FIS recruitment and presence on EAL education in BC's public schools is that in official Ministry of Education statistics, FIS and ELL have been treated as separate and completely different categories of student. Figure 1 illustrates, for example, provincially-mandated and publicly available statistics that display the numbers of Aboriginal, English Language Learner (ELL), French Immersion, and Non-Residents students in all of BC's K-12 schools between the 2012/13 and 2016/2017 school years (BCMoE, 2017). The label Non-

Residents (leftmost column, bottommost row) has been used in these statistics to enumerate students who are ineligible for provincial operating grant funding, and hence must pay fees to individual school districts to attend public schools (i.e., who are FISs). The label English Language Learner (ELL) [leftmost column, second row] conversely, has been reserved for students who are eligible for provincial operating grant funding, but are also eligible for specialized additional provincial funding for supplemental EAL support services. In short, 
Non-Residents has been a category used to establish that, for residency-related reasons (see Deschambault, 2015, pp. 85-124 for a fuller discussion), this specific group of learners is ineligible for any type of provincial education funding.

\begin{tabular}{|c|c|c|c|c|c|c|c|}
\hline & School & All Sc & ols & All Public & chools & $\begin{array}{l}\text { All Inder } \\
\text { Sch }\end{array}$ & dent \\
\hline & Year & $\#$ & $\%$ & $\#$ & $\%$ & $\#$ & $\%$ \\
\hline Aboriginal & $2012 / 13$ & 73154 & 11.5 & 68195 & 12.1 & 4959 & 6.7 \\
\hline & $2013 / 14$ & 72438 & 11.4 & 67428 & 12.1 & 5010 & 6.6 \\
\hline & $2014 / 15$ & 71194 & 11.2 & 65837 & 11.9 & 5357 & 6.6 \\
\hline & $2015 / 16$ & 70311 & 11.1 & 65212 & 11.8 & 5099 & 6.2 \\
\hline & $2016 / 17$ & 69032 & 10.8 & 63914 & 11.5 & 5118 & 6.1 \\
\hline English Language & $2012 / 13$ & 64714 & 10.1 & 61296 & 10.9 & 3418 & 4.6 \\
\hline Learner (ELL) & $2013 / 14$ & 64810 & 10.2 & 61395 & 11.0 & 3415 & 4.5 \\
\hline & $2014 / 15$ & 64646 & 10.2 & 61080 & 11.0 & 3566 & 4.4 \\
\hline & $2015 / 16$ & 66679 & 10.5 & 63093 & 11.4 & 3586 & 4.4 \\
\hline & $2016 / 17$ & 66285 & 10.3 & 62801 & 11.3 & 3484 & 4.2 \\
\hline French Immersion & $2012 / 13$ & 48309 & 7.6 & 47857 & 8.5 & 452 & 0.6 \\
\hline & $2013 / 14$ & 49892 & 7.9 & 49451 & 8.8 & 441 & 0.6 \\
\hline & $2014 / 15$ & 50860 & 8.0 & 50308 & 9.1 & 552 & 0.7 \\
\hline & $2015 / 16$ & 53091 & 8.4 & 52545 & 9.5 & 546 & 0.7 \\
\hline & $2016 / 17$ & 53768 & 8.4 & 53206 & 9.5 & 562 & 0.7 \\
\hline Non-Residents & $2012 / 13$ & 13040 & 2.0 & 10259 & 1.8 & 2781 & 3.7 \\
\hline & $2013 / 14$ & 14135 & 2.2 & 11073 & 2.0 & 3062 & 4.0 \\
\hline & $2014 / 15$ & 16958 & 2.7 & 13128 & 2.4 & 3830 & 4.7 \\
\hline & $2015 / 16$ & 18711 & 2.9 & 14639 & 2.6 & 4072 & 5.0 \\
\hline & $2016 / 17$ & 20438 & 3.2 & 15870 & 2.8 & 4568 & 5.5 \\
\hline
\end{tabular}

Figure 1. Student numbers in BC's K-12 schools (adapted from BCMoE, 2017, p. 2).

The BCMoE's use of funding eligibility to relationally construct and enumerate FISs as distinct from ELLs, as illustrated in Figure 1, is important for understanding a central, and contrasting, argument I wish to make in this article. The argument is that in K-12 public education practices these two categories of student are in fact very closely connected, that terms like international student and non-resident actually work to obscure that FISs are in effect fee-paying ELLs, and that international education ought first and foremost to be conceptualized as the commodification of EAL education. In fact, as I demonstrate in the remainder of the article, it is the omnipresent and often tacit treatment and representation of FISs as ELLs - in the talk and texts of students, teachers, administrators, and other stakeholders - that serves as the warrant for this argument. I suggest that these routinized constructions of FISs as ELLs are evidence of the multilayered socialization of public schooling by internationalization efforts in BC's K-12 sector, and that EAL education is the site most profoundly impacted by such FIS socialization (see also, e.g., Deschambault, 2015). 


\section{Literature Review: FISs in Studies Conducted in Canada}

Despite the growing trend to recruit FISs to K-12 public schools in both Canada and the United States that has been discussed in popular media outlets (e.g., Findlay, 2011, 2013; Goodnough, 2010; Hopkins, 2012; Marklein, 2015; Mitchell, 2004; Nuwer, 2014; Sambides Jr., 2013; Tang, 2014; Toppo, 2014; Weiss, 2014; Zheng, 2014), very few studies have focused explicitly on the experiences of FISs in public schools. Though some studies have made mention of the category of FIS (e.g., Duff, 2002), or conversely, have included FISs among the focal participants (e.g., Qian, 2012; Shin, 2010), only a handful among these have focused solely and explicitly on the reported experiences of FISs in public secondary schools (e.g., Arnott, 2012; Nelson, 2013; Popadiuk, 1998; Zheng, 2014).

Apart from Zheng (2014, summarized below), these FIS-centred studies have relied on data collected from single, one-off interviews with individual students (e.g., Popadiuk, 1998, 2009, 2010; Popadiuk \& Marshall, 2011), ${ }^{2}$ from single focus groups with two to six students at one time (Nelson, 2013), or from a combination of single individual interviews, a questionnaire, and field-notes (Arnott, 2012). Taken together, these studies suggest that EAL learning has been a central, and sometimes contradictory, locus of social and academic inclusion and exclusion for FISs. For example, Popadiuk and Marshall's (2011) interview study showed FISs discussing EAL learning in markedly different ways: as an impediment to academic progress; as an institutionally recognized linguistic capital that served as the basis for different curricula (i.e., English as a second language [ESL] vs. forcredit courses); as a pursuit that was hindered by their use of their first language; and as an arbitrator of social and cultural integration with both international and non-international student peers. Like many of the studies mentioned above, Popadiuk and Marshall characterized English, and students' perceptions of it, as "the much-sought-after world language of global and local importance that will bring new social, linguistic, and cultural capital (Bourdieu, 1994) to international students by facilitating success in their future lives" (p. 223).

More in-depth multiple-case study and ethnographic research has included FISs as a distinct, though not focal, category of participants (e.g., Duff, 2002; Qian, 2012; Shin, 2010). Whereas Shin's (2010) study subsumed the experiences of FISs, permanent residents of Canada (i.e., landed immigrants), and students who held Canadian citizenship under the cover term "visa students" (i.e., yuhaksaeng; Shin, 2010, p. viii, 45-49), the blurring of these categories of student under the cover term visa students rendered invisible very important institutional attributes that make each unique. Duff's (2002) ethnographic study identified Barb - an international student from Indonesia - among the 19 students who participated in the research. While it is noteworthy that Duff distinguished between Barb and the other ELLs in the school, neither Barb's institutional status as a fee-payer nor her individual experiences as a student were a focus of the study. Similarly, although Qian (2012) clearly articulated differences in the fee-paying versus non-fee-paying statuses of the late-arriving Chinese participants in her study, these differences were passed over to focus on similarities between late-arriving students. Although English language learning was identified as consequential for the few international students in each of these three studies, none focused specifically on FISs' school-based experiences nor on the implications of their fee-paying status as students, for classrooms, for schools, or beyond.

One of the most comprehensive studies of pretertiary FISs' experience conducted to date is a survey study commissioned by the Toronto District School Board (TDSB; Zheng, 
2014). The purpose of the TDSB-sponsored research was to gain a sense of "the academic achievement, school engagement and well-being of the international/visa students [i.e., FISs], in order to provide research evidence for examining existing policies and procedures to ensure the learning needs of international/visa students [we]re being met." (Zheng, 2014, p. 2). Working data from the TDSB's census for students in Grades 7-12 and arranging students according to cohorts, the study presented an aggregated account of 3,990 FISs' reported experiences across 8 school years. However, while the study provided a bigpicture narrative of FISs in relation to, and as distinct from, "regular TDSB students" (Zheng, 2014, p. 1), the discussion of in-school experiences was presented using a 3-point Likert-style scale (i.e., all the time/often, sometimes, rarely/never) and discussed FISs' responses to items regarding satisfaction and acceptance, safety and bullying, relationships with school staff, "classroom teaching and learning," and "class participation" (Zheng, 2014, pp. 19-23). The study did not include any information about EAL services, teaching, or learning; the sole mention of English language learning in FISs' experiences is as follows: "It should be noted that although most of them started their studies in TDSB secondary schools immediately upon their arrival, some students choose to go to private institutions first to learn English or other purposes before enrolling in a TDSB school" (Zheng, 2014, p. 6).

In contrast, Gunderson's (2007) account of the situation in schools in Abbottsford, $\mathrm{BC}$, drew direct attention to the FIS-EAL connection, through the suggestion that EAL services are differently conceptualized, divided, or delivered to fee-paying students (i.e., FISs-ELLs) versus non-fee-paying students (i.e., domestic ELLs) depending on any given number of management-level or structural issues. Some teacher-participants in Gunderson's study suggested this differentiation favoured FISs, as in the following example:

There is much more money for International students; they are often serviced at the expense of time for the immigrant population; they come at the front of the line; there are decreased services for the immigrant population; it is an elitist split (CIA Helping Teacher). (Gunderson, 2007, p. 40)

In conjunction with research that has generally drawn attention to FIS as a distinct category of student, or that has drawn attention to connections between FISs and EAL in moreexplicit (e.g., Arnott, 2012; Nelson, 2013; Popadiuk \& Marshall, 2011; Qian, 2012; Shin, 2010) or less-explicit ways (e.g., Duff, 2002; Fallon \& Paquette 2009; Fallon \& Poole, 2014; Zheng, 2014), Gunderson's study can be heard as a clarion call of sorts. In his words: "issues related to International students were extremely contentious . . . [w] hile the mandate of this [study] was to focus on ESL matters, not the International Program, it turns out that they are highly related and inter-woven issues" (Gunderson, 2007, p. 20).

These studies have suggested that a broader, ethnographic investigation of the relationship between FISs and EAL would offer a much-needed perspective to an understanding of the myriad of ways in which FISs are contributing to and gaining from the K-12 public educational landscape - not only in BC but also more generally in Canadian contexts. Further, outside Canada, such an investigation would offer an important contribution to conversations in contemporary applied linguistics and education-related research that have drawn attention to the role of globalization, migration, and/or transnationalism (e.g., Duff, 2012, 2014, 2015; Lo, Abelmann, Kwon, \& Okazaki, 2014; Talmy, 2015; Waters, 2014, 2015), marketization of the English language (e.g., Park \& Lo, 
2012a, 2012b; Park \& Wee, 2012), and the meaning of public education as it is ever more influenced by such processes and emplacement in transnational educational fields (e.g., Deschambault, 2015; Gerard, 2015, 2016; Willinsky, 2001). To be sure, the axis of salient issues for researchers in these areas includes both "the extent to which people [have] actively appropriate[d] mobility as a strategy for [language] education" (Park \& Bae, 2009, p. 367) and the extent to which, in response to reduced levels of state-funding for public education, pretertiary institutions from a variety of English-dominant countries have actively recruited fee-paying students from non-English dominant countries (e.g., Arber, 2009; Farrugia, 2014; Lewis, 2005; Leve, 2011; Matthews, 2002; Matthews \& Sidhu, 2005).

Given the ethnographic orientation to the phenomenon of FISs, and the ways such an investigation centres the notions of globalization and migration, in the next section I describe how language socialization (LS) and superdiversity are useful frames for understanding the relationship between FISs and EAL.

\section{Language Socialization (LS) in Superdiverse Settings}

The key theoretical framework informing the larger study is LS, which is useful for conceptualizing and understanding how language functions as a resource for the construction, circulation, and regulation of social categories and the attributes and activities to which they are linked (e.g., Baquedano-López \& Mangual Figueroa, 2011; Duff, 2008b, 2012; Duff \& Hornberger, 2008; Rymes, 2008; Schieffelin \& Ochs, 1986; Talmy, 2012; Wortham, 2005). In Ochs' (1986) oft-quoted phrase, LS is taken "to mean both socialization through language and socialization to use language" (p. 2); that is, by tracing how meanings are assembled via indexical links between instances of language use and the contexts in which language is used, a central aim of LS research is to account for "the many kinds of cultural knowledge and social relations that are learned both in and through language" (Talmy, 2012, p. 573). For this article, then, LS is helpful for understanding how the widespread treatment of FISs as ELLs evidences FISs' impact on BC's K-12 educational system. In short, it is helpful for understanding that vis-à-vis a wide range of practices, and in their talk and texts, students, teachers, administrators, and other stakeholders have been socialized to understand FIS issues as connected, in fundamental ways, to EAL services, teaching, and learning.

Talmy (2015) has suggested that LS is a useful conceptual frame for investigating "the growing complexities of ESL learning in superdiverse public school settings" (p. 365; see also, Deschambault, 2015; Duff, 2015). The notion of superdiverse, which refers to Vertovec's (2007) call for better, more rigorous descriptions of how complex coalescences of variables - among them "immigration statuses and their concomitant entitlements and restrictions of rights" (p. 1025) - are implicated in the experience of migration for people and institutions. Indeed, Baquedano-López and Mangual Figueroa (2011) have positioned LS as a robust framework for examining how such coalescences become relevant as (im-)migrant groups "negotiate participation in and influence new communities and social institutions" (p. 537); they have argued for LS-based studies that highlight "how immigrant groups socialize one another" and "how immigrant groups influence the cities or locales they inhabit" (p. 555).

In BC's superdiverse K-12 school settings, where migration, language learning, and

public education intersect, focusing on student categories (i.e., FIS vs. ELL) is one way to

The Canadian Journal of Applied Linguistics: 21, 2 (2018): 46-79 
understand the socializing impacts of international education on people and processes at different levels of BC's school system.

\section{Methodology, Methods, and Study Details ${ }^{3}$}

The data in this article were generated as part of a longitudinal study conducted in BC between 2011 and 2013 (Deschambault, 2015). Conceived as a linguistic ethnographic, multiple case study (e.g., Bartlett \& Vavrus, 2014; Creese, 2008; Duff, 2008a; Rampton et al., 2004), the methodological orientation of the larger study was to value prolonged engagement with participants and data, in-depth representation of contexts investigated, and a discourse analytic perspective (e.g., Blommaert \& Rampton, 2011; Bronson \& WatsonGegeo, 2008; Duff, 2008a; Duff \& Talmy, 2011; Rampton et al., 2004; Talmy, 2012; Wortham, 2008). I adopt the same orientation in this article, which means treating data as "descriptions, claims, reports, allegations, and assertions" (Potter \& Hepburn, 2008, p. 275) and foregrounding through the analysis "how people and events are described, and how, through the use of language, accounts are constructed" (Drew, 2006, p. 65; see also, e.g., Talmy, 2010a, 2010b). This orientation highlights that the FIS-EAL connection is salient in talk and text, how and why it is variously accomplished, and by whom it is used as a resource.

Unlike the larger study from which they are drawn, the analyses in this article necessarily draw on a small set of data selected from the larger corpus of classroom observations, research interviews, student work, and (school and policy) documents amassed during fieldwork at Quondam High School (QHS) and in interactions with stakeholders from the Pateo School District and the BC Ministry of Education between 2011 and 2013. ${ }^{4}$ Specifically, in what follows I draw on data from: The BC Jobs Plan (Government of BC, 2012b); interviews with Pateo School District administrators, as well as QHS teachers and FISs; student-produced classroom work; and student statistical information from a QHS classroom, the Pateo School District, and the BC Ministry of Education.

\section{Analysis 1: FIS as ELL in Policy, Statistics, and Classroom Composition}

\section{The BC Jobs Plan}

The first data extract is taken from Canada Starts Here: The BC Jobs Plan (Government of BC, 2012b), a document whose title (Canada Starts Here) is a telltale hint at the geographic area targeted by the strategies constituting the plan: Asia Pacific. Given BC's western location as "the first point of call for people and goods", it has "both the opportunity and the obligation to lead our country across the ocean and secure our place in the emerging economies of the Asia Pacific"; indeed, this means mobilizing BC's strong points and "converting them into competitive advantages to turn opportunity into lasting economic benefit for all British Columbians" (Government of BC, 2012b, p.1). Foregrounded in the document among BC's "Infrastructure Sectors" is one of BC's "greatest strengths" (p.14) —its education system: 
Extract 1. From The BC Jobs Plan section entitled "International Education" (Government of BC, 2012b, p. 14)

01 B.C.'s education system is among the world's best and, while we've always counted on it to prepare our

02 children and youth for the future, we've barely begun to tap its potential to support our economic

03 growth. With rapid economic expansion in Asia Pacific countries, more parents than ever before want

04 their children to receive an English-language education - and we have growing opportunities to attract

05 and retain a much higher number of international students.

06 Many of these students will stay and build careers in British Columbia, helping to offset the impacts of

07 our aging population and ensuring employers have access to a highly skilled workforce. In the shorter

08 term, international students support local economies by paying for tuition, accommodation and living

09 expenses and help support our educational institutions deliver high quality education for B.C. students.

In Extract 1, BC's education system is constructed as a commodity-like resource that can benefit residents of $\mathrm{BC}$. For example, not only does it have the "potential to support our [BC's] economic growth" (line 02), it can "support local economies" (line 08), and "support our educational institutions [to] deliver high quality education for B.C. students" (line 09). The object of these benefits, the audience for whom the document is constructed, is indexed through the use of a collective we (or our) multiple times in the extract (lines 01, 02, 04, 07, 09). Arguably, the treatment of BC's education system as a salable product in The BC Jobs Plan is scaled up from its evocation in Bill 34-2002: The School Amendment Act (Bill 34, 2002). That is, evident here is a shift from the incitement to recruit international students as a source of school district revenue in Bill 34 to one which frames "BC's [K-12] education system" as a source of provincial government revenue (lines 02-03 and 07-09). Indeed, international education is constructed as a pathway to longer term migration which is mutually beneficial for migrants and the state (lines 06-07; see, e.g., Robertson's, 2013, work on the education-migration nexus).

Given the geographical reference to Asia Pacific countries keyed in the title of The $B C$ Jobs Plan, it is relevant to note that this market for BC's education system as commodity is composed primarily of jurisdictions where English is neither a dominant nor commonly-used language in the wider societies (i.e., in mainland China or South Korea, for example). ${ }^{5}$ Because the market for BC's education system is thus reliant on non-English dominant (student- and parent-) consumers, the relationship between FISs and EAL is very much implied through this construction. In a more explicit sense however, projected onto parents from these Asia-Pacific markets, is the desire for "their children to receive an English-language education" (lines 03-04); this is a more overt example of how EAL education is connected, indeed conflated or equated, with international education.

Extract 1 thus illustrates how a purportedly economic policy centered around jobs, vis-à-vis a market ideological approach to BC's public education system, can double as an understated language (education) policy. Discursively framing what is in effect the commodification of EAL education as "international education" in such a document is possible only because educational discourse and practices that embed the FIS-EAL connection have already been normalized and hence are unremarkable. However, despite the equating of international education with English language education in The BC Jobs Plan, not referred to anywhere in the document is how "attract[ing] and retain[ing] a much higher number of international students" (lines 04-05) might relate to the rights of other (im/migrant) students, to EAL learning or teaching, or to the function of public education. 


\section{FISs and ELLs in Student Statistics}

At the same time that the BC Government recognizes "English language proficiency" as an important factor when assessing "target countries" in its own International Education Strategy (Government of BC, 2012a, pp. 14-15), and endorses the expectation "that [K-12] international students [FISs] would receive the same appropriate level of service as their BC resident peers" where EAL services are concerned (BCMoE, 2013, p. 13), ${ }^{6}$ its provincial student statistics treat FIS and ELL as different categories of learners (see Figure 1 and Table 1). As I pointed out earlier in the article, the funding for this same appropriate level of service is thus not guaranteed by the $\mathrm{BCMoE}$; rather, it is left primarily to school districts, to which FIS tuition fees are paid, but also depends on administrative decisions at the school level.

Table 1 illustrates provincially-mandated, publicly available statistics for the student categories of ELL and Non-Residents (i.e., FISs) ${ }^{7}$ in all of BC's schools between the 2011/12 and 2016/2017 school years (BCMoE, 2016, 2017). As Table 1 suggests, since the year I began my fieldwork (2011/12), the number of Non-Residents students attending K-12 public schools in $\mathrm{BC}$ has increased by 6,088 (i.e., from 9,872 to 15,870). In contrast, the number of $E L L$ students attending K-12 public schools have shown a significantly smaller increase of just 722 (i.e., from 62,079 to 62,801).

Table 1

Statistics for the Student Categories of English Language Learner (ELL) and NonResidents (adapted from BCMoE, 2016, 2017)

\begin{tabular}{llllll}
\hline \multirow{2}{*}{ Category of Student } & \multicolumn{2}{c}{ All Schools } & \multicolumn{2}{c}{ All Public Schools } \\
\cline { 3 - 6 } & School Year & $\#$ & $\%$ & $\#$ & $\%$ \\
\hline ELL & $2011 / 12$ & 65275 & 10.2 & 62079 & 10.9 \\
& $2012 / 13$ & 64714 & 10.1 & 61296 & 10.9 \\
& $2013 / 14$ & 64810 & 10.2 & 61395 & 11 \\
& $2014 / 15$ & 64646 & 10.2 & 61080 & 11 \\
& $2015 / 16$ & 66679 & 10.5 & 63093 & 11.4 \\
& $2016 / 17$ & 66285 & 10.3 & 62801 & 11.3 \\
Non-Residents & & & & & \\
& $2011 / 12$ & 12588 & 2 & 9782 & 1.7 \\
& $2012 / 13$ & 13040 & 2 & 10259 & 1.8 \\
& $2013 / 14$ & 14135 & 2.2 & 11073 & 2 \\
& $2014 / 15$ & 16958 & 2.7 & 13128 & 2.4 \\
& $2015 / 16$ & 18711 & 2.9 & 14639 & 2.6 \\
& $2016 / 17$ & 20438 & 3.2 & 15870 & 2.8 \\
\hline
\end{tabular}

Of interest here, and something the Government of $\mathrm{BC}$ has tacitly recognized in its own policy documents (i.e., Extract 1; see also, e.g., BCMoE, 2013; Government of BC, 2012a), is what both categories of student most often share: that their "primary language, or languages of the home, are other than English" and, as a result, that they "require additional services to develop their individual potential within [BC's] school system" (BCMoE, 2009, 
p. 4). For this reason, I argue that the relational construction and enumeration of FISs as distinct from $\mathrm{ELLs}^{8}$ renders the BCMoE accounts of the number of ELLs in the province at best unreliable, and at worst, disingenuous. In fact, as I report below, support for this claim can be traced to changes the Pateo School District made in the categories it used to generate district-level student statistics — changes that combined the BCMoE's Non-Residents and ELL categories into one label: ELL-International.

Given what I had learned during fieldwork at QHS about the proportion of FISs who were receiving EAL services (i.e., that it was quite high), I contacted the Pateo School District to inquire as to whether they knew the proportion of FISs who were also receiving EAL services at the district level. A district representative responded with the news that, beginning in 2011/12, the district had developed "a new program code ELL-International to track the number of international students [i.e., FISs] who also receive ELL support services" (D. Représ, personal communication, October 2, 2012). Since these data were not made freely available to the public, I requested access and received numbers from the 2011/12 through 2013/14 school years.

Table 2 shows the number and percentage of FISs receiving EAL services in the Pateo School District between 2011/2012 and 2013/2014 school years respectively. The data collected under the Pateo School District's new ELL-International category establish not only that a substantial number of its FISs make use of EAL services, but further that this number had increased by almost 15\% between the 2011/12 and 2013/2014 school years. Whereas in the 2011/12 school year 58\% of FISs in the Pateo School District relied on ELL educational support, by $2013 / 2014$ this had increased to almost $73 \%$.

Table 2

Fee-Paying International Students (FISs) Receiving English Language Learner (ELL) Services in the Pateo School District

\begin{tabular}{llll}
\hline & \multicolumn{3}{l}{ School Year } \\
\cline { 2 - 4 } Pateo School District Students & $2011 / 2012$ & $2012 / 2013$ & $2013 / 2014$ \\
\hline Non-Residents (i.e., FISs) & 1048 & 1057 & 1258 \\
ELL-International (i.e., FISs-ELLs) & 609 & 757 & 917 \\
$\%$ of FISs receiving ELL services & 58.1 & 71.6 & 72.8 \\
\hline
\end{tabular}

Not only did the district's new categories purposefully diverge from those used in/for the BCMoE's provincially-mandated student statistics, the fact that the Pateo School District had a need to create the new ELL-International category indicates their interest in better understanding how FIS presence was impacting EAL services, teaching, or learning. This need for, and emergence of, the new category is thus one example of FIS socialization; it is an index, manifested in language, of how and where international education and FISs are impacting the district's schools-EAL education.

Beyond evidencing socialization, the Pateo School District's ELL-International category suggests the BCMoE's persistent treatment and enumeration of FISs as distinct from ELLs is problematic and potentially deceptive. In the Pateo School District, as Table 2 shows, there were a significant number of FISs who were also receiving EAL services in 2011/12 (i.e., 609), 2012/2013 (i.e., 757) and 2013/2014 (i.e., 917), but none of these ELLInternational learners are included in the BCMoE's ELL numbers for the corresponding years in Table 1. Because the Pateo School District is just one example, any number of questions arise: Do the BCMoE categories facilitate misrepresentation of the actual number 
of ELLs in BC's public schools? What if the percentage of FISs making use of EAL services were equally as high across all districts in the province? How might the inclusion of FISs-ELLs in the overall provincial counts have an impact on (ELL) funding policy, if at all?

\section{FISs in ELL Classes at QHS}

In my observations over the course of the 2011/2012 school year at QHS, the significance of FISs for EAL programs, teaching, and learning was intense and noteworthy. In each of the two classes I observed, the FISs who participated in the study ${ }^{9}$ represented approximately one third of the class composition. Data in Figures 2 and 3 were generated via a self-report survey completed by students in March of 2012. The names of and information relating to all FIS students who participated in the study are presented in bolded font against a shaded background for both Ms. Jay's (Figure 2) and Mr. Whee's (Figure 3) ELL classes. In Ms. Jay's ELL class of 30 students, 10 of the students who participated in my study were FISs; in Mr. Whee's ELL class of 30 students, nine of the students who participated in my study were FISs (Figures 2 and 3 are adapted from Deschambault, 2015, p. 57, 60).

The composition of these classrooms might also be framed as having important (and arguably more material) socializing consequences for the conditions under which EAL education occurred at QHS. The first consequence is again related to statistics, and in some ways helps to explain the Pateo School District's creation of the ELL-International category: Even though FIS presence had substantially altered the size of each ELL class, none of the FISs in Ms. Jay's or Mr. Whee's classes would have been accounted for as ELLs in publicly available, provincially collected, student statistics. The second consequence relates to funding: Despite the fact that approximately $30 \%$ of all students in each class were ineligible for specialized additional funding for ELLs from the BCMoE, there was (and remains) no public record of how, at the district or school level, FIS revenues were (or were not) being allocated specifically to bolster the provision of ELL services and/or education. Yet another consequence relates to the learning context in Ms. Jay and Mr. Whee's classes, where a widely shared student goal was to "get out of ESL as soon as possible" (Zeejay, Figure 4): FISs-ELLs and domestic ELLs now had to engage in heightened forms of soft competition for the school support necessary to be promoted out of ELL and into classes for which they would receive credit for graduation (e.g., Wild, Helmer, Tanaka, \& Dean, 2006).

In the next analytic section, I draw on interview data to further demonstrate how the connection between FISs and EAL is salient in the accounts of administrators, teachers, and students. 


\begin{tabular}{|c|c|c|c|c|c|c|c|}
\hline Pseudonym & Age & $\mathrm{Gr}$ & $\begin{array}{l}\text { Place } \\
\text { of Birth }\end{array}$ & $\begin{array}{c}\text { Citizen or } \\
\text { Permanent } \\
\text { Resident? }\end{array}$ & $\begin{array}{l}\text { Languages } \\
\text { other than } \\
\text { English }\end{array}$ & $\begin{array}{c}\text { Time in BC } \\
\text { School } \\
\text { (as of March } \\
\text { 2012) }\end{array}$ & $\begin{array}{l}\text { Live with } \\
\text { Parents? }\end{array}$ \\
\hline WoW & 16 & 10 & Korea & No & $\begin{array}{l}\text { Korean; } \\
\text { German }\end{array}$ & 2 years & No \\
\hline Bone & 16 & 10 & China & No & Mandarin & 7 months & No \\
\hline Bessie & 16 & 10 & China & No & Mandarin & 14 months & No \\
\hline Thin-man & 16 & 10 & China & No & Mandarin & 6 months & No \\
\hline $\mathrm{CC}$ & 16 & 10 & China & No & Mandarin & 7 months & No \\
\hline like2sk8 & 15 & 10 & China & No & Chinese & 6 months & No \\
\hline MJ**10 & 15 & 10 & Korea & No & Korean & 1 year & Yes \\
\hline bsidelk2sk8 & 15 & 10 & China & No & Chinese & 6 months & Yes \\
\hline Neon** & 14 & 9 & China & No & Mandarin & 7 months & No \\
\hline Hawaii & 14 & 9 & China & No & Mandarin & 7 months & No \\
\hline @ front & 18 & 12 & China & Yes & $\begin{array}{l}\text { Mandarin; } \\
\text { Cantonese }\end{array}$ & 7 months & Yes \\
\hline Who & 16 & 11 & China & Yes & Wuhanese & 6 months & Yes \\
\hline SLA & 16 & 10 & Brazil & $\begin{array}{l}\text { Study } \\
\text { Visa }\end{array}$ & Portuguese & 6 months & Yes \\
\hline North & 15 & 10 & China & Yes & Chinese & 13 months & Yes \\
\hline Nita*11 & 15 & 10 & China & Yes & Mandarin & 1 months & Yes \\
\hline VW & 14 & 9 & China & Yes & Mandarin & 7 months & Yes \\
\hline $\mathrm{CaLu}$ & 14 & 8 & China & Yes & Mandarin & 6 months & Yes \\
\hline ZB & 14 & 8 & China & Yes & Chinese & 3 months & Yes \\
\hline $\mathrm{Rad}$ & 13 & 8 & UAE & Yes & Arabic & "years" & Yes \\
\hline $\mathrm{CK}$ & 13 & 8 & Taiwan & Yes & Mandarin & 7 months & Yes \\
\hline Flower & 13 & 8 & China & Yes & Mandarin & 2 months & Yes \\
\hline \multicolumn{8}{|l|}{ Student } \\
\hline \multicolumn{8}{|l|}{ Student } \\
\hline \multicolumn{8}{|l|}{ Student } \\
\hline \multicolumn{8}{|l|}{ Student } \\
\hline \multicolumn{8}{|l|}{ Student } \\
\hline \multicolumn{8}{|l|}{ Student } \\
\hline \multicolumn{8}{|l|}{ Student } \\
\hline \multicolumn{8}{|l|}{ Student } \\
\hline Student & & & & & & & \\
\hline
\end{tabular}

Figure 2. Ms. Jay's English language learner (ELL) class: Fee-Paying international student (FIS) and English language learner (ELL) participants. 


\begin{tabular}{|c|c|c|c|c|c|c|c|}
\hline Pseudonym & Age & Gr & $\begin{array}{l}\text { Place } \\
\text { of Birth }\end{array}$ & $\begin{array}{l}\text { Citizen or } \\
\text { Permanent } \\
\text { Resident? }\end{array}$ & $\begin{array}{l}\text { Languages } \\
\text { other than } \\
\text { English }\end{array}$ & $\begin{array}{c}\text { Time in BC } \\
\text { School } \\
\text { (as of March } \\
\text { 2012) }\end{array}$ & $\begin{array}{l}\text { Live with } \\
\text { Parents? }\end{array}$ \\
\hline WoW & 16 & 10 & Korea & No & $\begin{array}{l}\text { Korean; } \\
\text { German }\end{array}$ & 2 years & No \\
\hline Bone & 16 & 10 & China & No & Mandarin & 7 months & No \\
\hline Bessie & 16 & 10 & China & No & Mandarin & 2 years & No \\
\hline Zeejay & 15 & 10 & China & No & $\begin{array}{l}\text { Mandarin; } \\
\text { Cantonese }\end{array}$ & 7 months & No \\
\hline Wanda** & 15 & 10 & $\begin{array}{l}\text { Hong } \\
\text { Kong }\end{array}$ & No & $\begin{array}{l}\text { Cantonese; } \\
\text { some } \\
\text { Mandarin }\end{array}$ & 7 months & No \\
\hline Thin-man & 16 & 10 & China & No & Mandarin & 6 months & No \\
\hline $\mathrm{CC}$ & 16 & 10 & China & No & Mandarin & 7 months & No \\
\hline like2sk8 & 15 & 10 & China & No & Chinese & 6 months & No \\
\hline MJ** & 15 & 10 & Korea & No & Korean & 1 year & Yes \\
\hline Sumyar & 17 & 11 & China & Yes & $\begin{array}{l}\text { Mandarin; } \\
\text { Cantonese }\end{array}$ & 6 months & Yes \\
\hline Who & 16 & 11 & China & Yes & Wuhanese & 6 months & Yes \\
\hline YA & 16 & 10 & China & Yes & Mandarin & 2 years & Yes \\
\hline Nita* & 15 & 10 & China & Yes & Mandarin & 1 months & Yes \\
\hline Eww & 15 & 10 & China & Yes & Mandarin & 7 months & Yes \\
\hline $\mathrm{HaZ}$ & 15 & 9 & China & Yes & Mandarin & 7 months & Yes \\
\hline JR & 14 & 9 & China & Yes & Mandarin & 7 months & Yes \\
\hline Zard & 14 & 9 & Pakistan & No & $\begin{array}{l}\text { Pushto; } \\
\text { Urdu }\end{array}$ & 20 months & Yes \\
\hline Aha & 14 & 9 & China & Yes & Mandarin & 2 years & Yes \\
\hline VW & 14 & 9 & China & Yes & Mandarin & 7 months & Yes \\
\hline $\mathrm{NaPa}$ & 14 & 9 & China & Yes & Mandarin & 1 months & Yes \\
\hline Lolz & 14 & 8 & Korea & Yes & $\begin{array}{l}\text { Korean; } \\
\text { Japanese }\end{array}$ & 1 year & Yes \\
\hline myZ & 14 & 8 & China & Yes & Chinese & 2 years & Yes \\
\hline Flower & 13 & 8 & China & Yes & Mandarin & 2 months & Yes \\
\hline iTelos & 13 & 8 & Brazil & No & Portuguese & 6 months & Yes \\
\hline St & 13 & 8 & Iran & Yes & Farsi & 4 months & Yes \\
\hline ZB & 14 & 8 & China & Yes & Chinese & 3 months & Yes \\
\hline RAD & 13 & 8 & UAE & Yes & Arabic & "years" & Yes \\
\hline \multicolumn{8}{|l|}{ Student } \\
\hline \multicolumn{8}{|l|}{ Student } \\
\hline Student & & & & & & & \\
\hline
\end{tabular}

Figure 3. Mr. Whee's English language learner (ELL) class: Fee-Paying international student (FIS) and English language learner (ELL) participants.

\section{Analysis 2: FISs as ELLs in Interview Accounts and Student Work}

In this section, I present examples from research interviews with a Pateo School District administrator, as well as the principal, an EAL teacher, and two FISs from QHS. Each instance demonstrates how, for a variety of participants from different levels of the school system, the discursive construction of FIS as ELL was a well-established, widely circulating, and everyday practice. 


\section{Pateo School District Administrator}

In Extract 2, the administrator (IEP) draws on the example of a "rural" school district ("Salish Stream," line 02) to work up an explanation for why teachers in the Pateo School District ("here," line 07) did not know the difference between FIS and domestic ELL students:

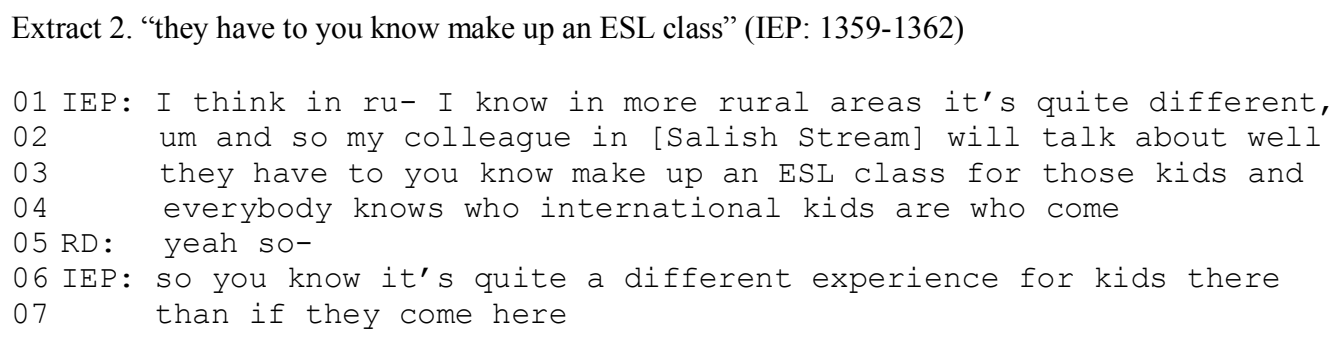

The description IEP gives of what happens in "more rural areas" (line 01) is remarkable in the way it uses EAL services (i.e., "an ESL class", line 03) as a resource for constructing the experiences of FISs (i.e., "those kids", line 03). In the account, EAL services are positioned as playing a critical mitigating role in FISs' school experiences: Whereas in an urban setting like the Pateo School District, ELL classes are so ubiquitous and taken for granted that FISs can be placed in existing classes (not to mention go unnoticed by teachers who are unable to distinguish between domestic ELLs and FISs-ELLs), ${ }^{12}$ in rural areas it is necessary to "make up an ESL class for those kids [i.e., FISs]" (line 03) because prior to FISs' arrival ELL classes did not exist.

The account given by IEP is premised on an ideological orientation to FISs as de facto ELLs. In a different part of our interview (Deschambault, 2015, p. 156-157), I had stated that it was difficult for me to understand why, if FISs were paying close to $\$ 1000$ per month in homestay fees and over $\$ 13,000$ in yearly tuition fees, their parents did not prefer to send them to a private school. The response from IEP was to specify that "one reason is that many private schools don't have an ESL program", and to note that in the Pateo School District they did not "screen out" FISs based on English proficiency levels (i.e., "we absolutely don't we're welcoming to any students in any ESL level” [Deschambault, 2015, p. 156]). Not only did this response construct FISs as frequently requiring EAL services, it implied that FISs attend public (and not private) schools specifically because they require EAL services.

More broadly, the links IEP constructs between FIS experience and EAL education in public schools are salient precisely for the way they are treated: as unremarkable and taken-for-granted. This treatment of EAL education as an inevitable site of FIS impact, and in this instance within broader (i.e., urban/rural, private/public) educational marketplaces, is a further index of the "kinds of cultural knowledge and social relations that are learned both in and through language" (Talmy, 2012, p. 573).

\section{QHS Principal and Ms. Jay}

Extract 3 is part of a larger account by the QHS principal (QP) of a situation in which, at the end of the 2011/2012 school year, 30 students had decided to leave QHS to attend a different high school. The extract begins with QP presenting details of students 
who had decided to leave, and has been included here for the way it describes "international students" (line 02; i.e., FISs).

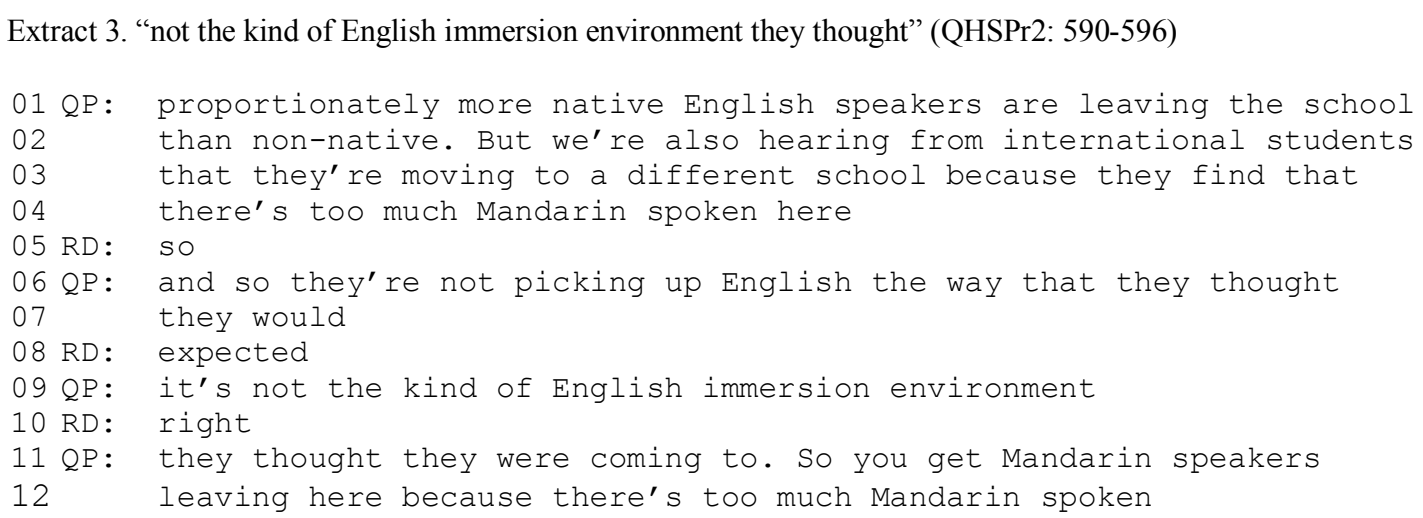

In this extract, QP uses indirect reported speech (Bolden, 2004; Clark \& Gerrig, 1990; Holt, 2007) to provide a general account for why FISs have decided to leave QHS, suggesting the decision is explicitly connected to their perception of the environment for learning English. Not only did QP "hear from" FISs that they were "not picking up English the way that they thought they would" (line 06-07), the principal also stated that QHS was "not the kind of English immersion environment [RD: right] they thought they were coming to" (lines 09-11). Bound up in QP's use of the indirect reported speech as part of this account are characterizations of FISs as ELLs (i.e., their need, desire, and/or struggle to "pick up English", line 06), and similarly of their purpose for coming to BC as being directly linked to English language education (i.e., their need, desire, and/or struggle to find a suitable "English immersion environment"). That "too much Mandarin" (lines 04, 12) was FISs' ostensive reason for leaving QHS is further evidence of the attribution of ELL status to these students, in the sense that they are constructed as first language Mandarin speakers.

My interviews with teachers at QHS were replete with references to EAL services, teaching, and/or learning as a means for describing facets of FISs' experience. Extract 4 is from a sequence in which Ms. Jay puts forth two possible reasons FISs come to Canada to study.

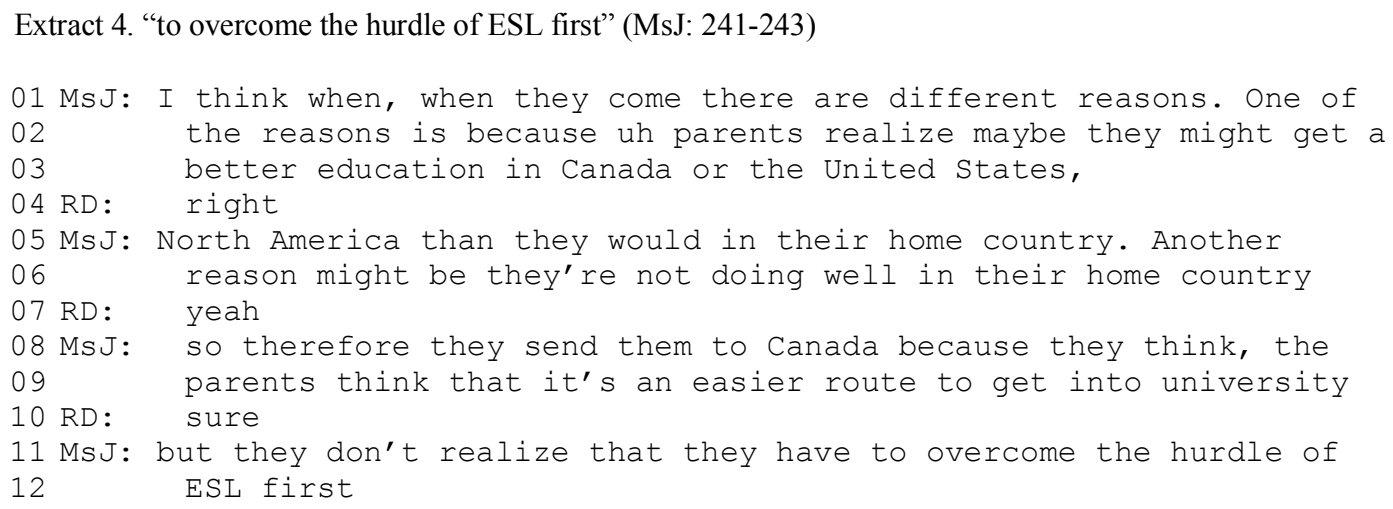

Ms. Jay first attributes to FISs' parents the understanding that their children "might" receive a "better education" in Canada "than they would in their home country" (lines 02- 
05) and, secondly, that because FISs may "not doing well in their home country", sending them to study overseas might be "an easier route to get into university" (lines 05-09). Most significant in this account, however, is the way in which Ms. Jay situates the candidate reasons for coming as inconsequential relative to students' English language skills: "but they [parents] don't realize they [students] have to overcome the hurdle of ESL first" (lines 11-12). Ms. Jay's account in Extract 4 is thus another instance in which, in and through language, a public education insider attributes to FISs the taken-for-granted status of ELL, and at the same time performs the widely-accepted practice of equating international education with EAL education.

But in this case the "hurdle of ESL" (lines 11-12) to which Ms. Jay refers is doubly pertinent: Over and above treating English language learning as a defining feature of FISs' educational experience, the "need to overcome the hurdle of ESL" (lines 11-12) alludes to a key structural issue standing in FISs' way of "a better education" (lines 02-03) or "an easier route to get into university" (line 09) - namely that ELL courses "are not awarded credit towards graduation" (Wild et al., 2006, p. 6).

\section{Moon and Zeejay}

One of the pervading narratives produced by the Pateo School District administrator, as well as by both teachers and students at QHS, was what I refer to as the "no differences" narrative; namely, that many participants reported not knowing which students were FISsELLs and which students were domestic ELLs (see, e.g., endnote 13). In Extract 5, Moon (a female, focal FIS participant) uses this no differences narrative as a means for responding to an interview question I had asked about differences between FISs-ELLs and domestic ELLs in her class.

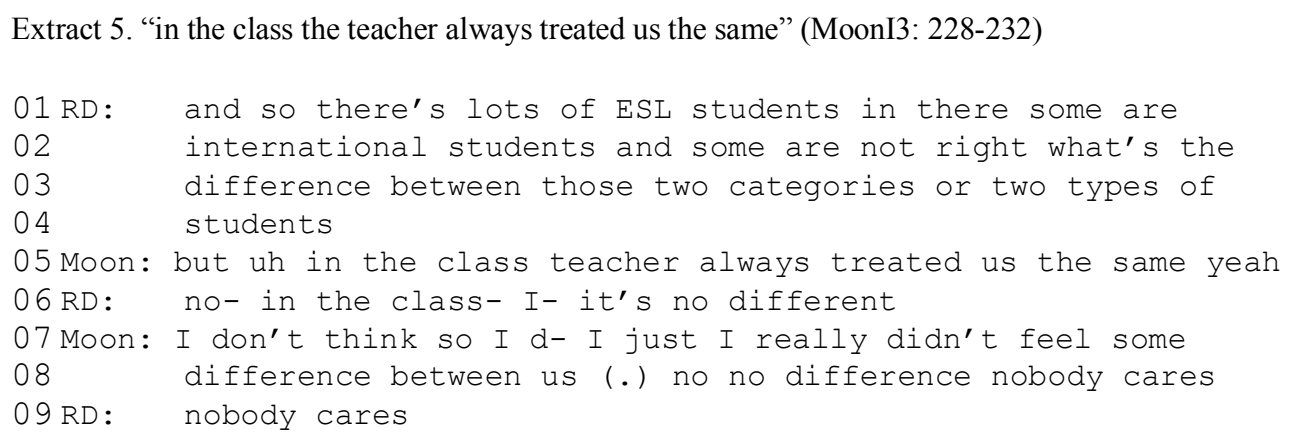

Moon rejects the candidate distinction between FISs-ELLs and domestic ELLs that is embedded in my line 02-04 question. She accomplishes this rejection by drawing on the locally salient no differences narrative, which she mobilizes via an account of teacher behaviour (i.e., "the teacher always treated us the same" [line 05]), appeals to her own experiences (i.e., "I don't think so"; "I really didn't feel" [line 07]), and a characterization of the culture at QHS (i.e., "nobody cares" [line 08]). That this no differences narrative itself is premised on the similarities between FISs-ELLs and domestic ELLs, and that she so ably recruits it as an resource in the interview, further signals the extent to which FIS presence is having a socializing impact on EAL education and the (discursive construction of) ELL experience. 
The final student example is drawn from an essay produced by a male focal FIS participant named Zeejay (Figure 4). The essay, entitled "Chinese International Student in Canada," was part of a larger writing assignment students had been asked to complete in Mr. Whee's ELL class. The assignment was graded and filed as a sample to be used during evaluations of students' English proficiency (see, e.g., Deschambault, 2015, pp. 243-254, 383-386). Figure 4 displays the first two sentences of the essay's second paragraph.

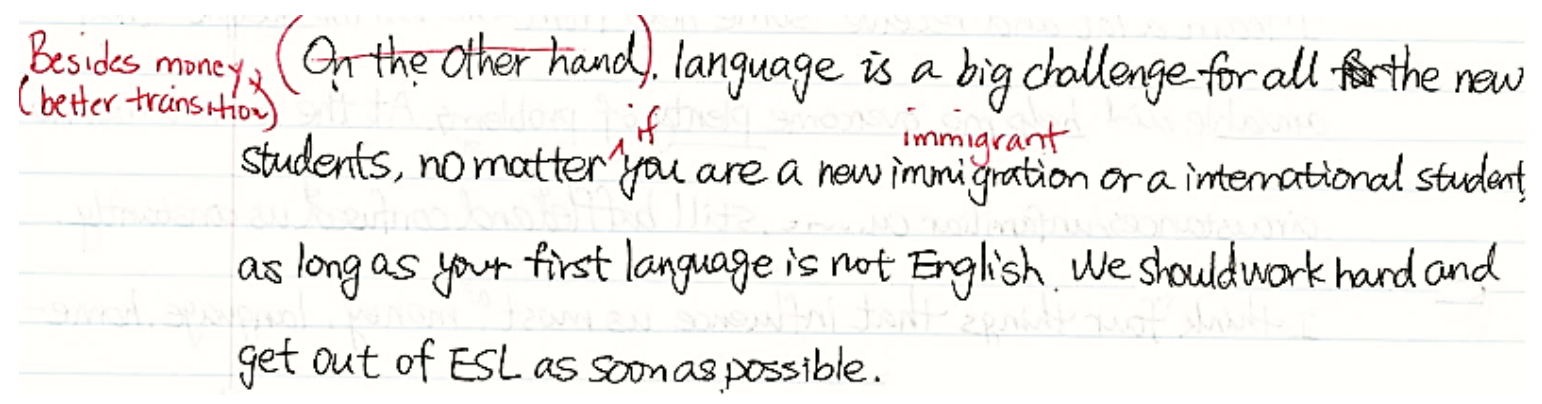

Figure 4. Zeejay's essay: “Chinese International Student in Canada” (ZJ: P14).

By treating students' needs as indistinguishable, Zeejay mobilizes the no differences narrative in quite a different way than Moon. Zeejay's assertions that, (a) "language is a big challenge" for both FISs-ELLs and domestic ELLs (i.e., "new immigration") because their "first language is not English"; and (b) both groups of students are engaged in an identical institutional pursuit (i.e., "We should work hard and get out of ESL as soon as possible"), are indices of widely circulating practical understandings at QHS and more broadly in the Pateo School District. But while Zeejay's use of the no differences narrative in Figure 4 was as a resource to complete the academic task he had been assigned by Mr. Whee, the assignment itself has mediated the (re)production of and (re)circulation of the notion not only that FISs are in effect fee-paying ELLs, but also the notion that EAL teaching and learning - and specifically getting out of ESL — is foundational to the FIS experience.

In his marshaling of language for this essay, Zeejay draws upon and embeds cultural knowledge, social relations, and locally relevant practices regarding FIS experience in a BC school. The availability of these resources for use, and his knowledge that they will be rhetorically salient for (and comprehensible to) his audience (i.e., Mr. Whee), again are evidence of how international education and FISs are having a socializing impact in public schools.

\section{Discussion}

Recalling the title of the article_- "Fee-Paying English Language Learners:

Situating International Students' Impact on British Columbia's Public Schools"-may be a useful starting place for recapitulating my aim in this article. To augment existing FISrelated research in Canada, and in alignment with education-related and applied linguistics work that has taken interest in how globalization, migration, and/or transnationalism are related to English language learning in K-12 contexts, I have situated the recruitment and presence of FISs as having a fundamental and consequential relationship to EAL education. To do so I have drawn attention to (a) the deployment of "tacit knowledge of principles of social order and systems of belief" (Ochs, 1986, p. 2) about FISs, specifically as such knowledge is produced and circulated in data from multiple sources within BC's public 
education system; and (b) data that demonstrate how the recruitment and presence of FISs can have a material impact on the classroom conditions for EAL learning and teaching (i.e., student statistics, classroom demographics).

In the first analytic section, I demonstrated how FISs are treated as ELLs in different ways in policy and statistical documents, and how FIS presence was relevant to the classroom composition of two classes observed during my fieldwork. In the case of The BC Jobs Plan (Government of British Columbia, 2012b), the analysis drew attention to how international education is equated with EAL learning, and thus by extension, how FISs are constructed as fee-paying ELLs. The discrepancy between the BC Government's construction of FISs as ELLs in The BC Jobs Plan, and, for instance, the BCMoE's work to obscure connections between FIS and ELL in student statistics by treating them as separate categories (e.g., BCMoE, 2016, 2017; Table 1), is thus an illustrative instance of how complex coalescences of variables can impact the experiences of educational migration for both people and institutions (e.g., Vertovec, 2007). Whereas in The BC Jobs Plan there is no undesirable consequence for equating K-12 international education with EAL learning, drawing this type of connection in provincial student statistics has implications for education finance - and hence is avoided. Both The BC Jobs Plan and provincial student statistics construct FISs in different ways, and according to specific rhetorical and institutional logics that do not necessarily align; and yet, in their purposive constructions of FISs, both are emblematic of how this group of migrant students is having a socializing influence on K-12 public education in BC (see, e.g., Baquedano-López \& Mangual Figueroa, 2011). This socializing influence is further traced through the contrasting of BCMoE student categories with those of the Pateo School District. While in the publicly available record of student statistics published by the BCMoE the link between FISs (i.e., Non-Residents) and ELLs is effectively obscured, the Pateo School District's establishment of the locally relevant ELL-International category suggests that school district-level stakeholders were not only aware of, but also demonstrably concerned about, the connection between FIS presence and EAL education and the impact of the former on the latter. And as the classroom composition of Mr. Whee's and Ms. Jay's classes at QHS suggests, the district had good reason to be concerned: $30 \%$ of the students in each class were ELL-International and their presence thus increased each teacher's workload and diminished the amount of classroom support domestic ELLs might otherwise have received. This is an especially important issue given that FIS revenues are managed by school districts and individual schools (and not the BCMoE), and it is exacerbated by the fact that it remains unclear-especially in the case of EAL education - to whom the responsibility for creating policy regarding the use of FIS revenues ought to fall.

In the second analytic section, I demonstrated how FISs are treated as ELLs across a range of accounts produced by administrators, teachers, and students. Even though each of the five accounts was generated for different purposes (i.e., in research interviews or for a classroom assignment), and in different contexts, what each has in common is the way it constructs FISs' experience as inextricably connected with EAL learning and teaching. I argue that the descriptions of FISs as ELLs in these accounts, and the ways administrators, teachers, and students position EAL learning and teaching as foundational to the FIS experience - are evidence of FIS socialization; they catalogue what FIS socialization is, where it has impact, and how prevalent and ubiquitous it has become across levels of the education system. 
The widespread treatment and quotidian acknowledgement of FISs as ELLs strongly suggests that in practice, $\mathrm{K}-12$ international education in $\mathrm{BC}$ is very much a euphemistic, officially unrecognized, commodification of EAL education (see also, e.g., Deschambault, 2014, 2015). The data and analyses I have presented in this paper support the claim that EAL education is a critical site of FIS socialization and impact, and hence is an issue that ought to receive more attention in both research and practice. Especially in the context of vigorous and ongoing discussions about funding in contemporary K-12 public education in BC (e.g., BCMoE, 2018; Fallon \& Poole, 2014; Kuehn, 2014; Li \& Thomas, 2016; Melnychuk, 2016; Pawson, 2016; Poole \& Fallon, 2015; Zeidler, 2016), the ubiquity of the FIS-EAL connection and the unaccounted-for impact of FISs on EAL education is cause for serious concern. Overwhelmed as districts are with "cumulative structural shortfalls . . . that have resulted in school closures, larger classes, and the loss of educational programs" (White, 2012, p. 2), EAL education across the province has not gone unscathed. For example, despite an increase in the number of ELLs between 2001/2 $(N=$ 59,343; BCMoE, 2010, p. 14) and 2016/17 ( $N=62,801$; Table 1$)$, there has been a loss of 283 ELL specialist teachers during the same period (BCTF, 2017, p. 1). Parallel to these changes in ELLs and ELL teacher numbers, the number of FISs has increased massively over the same period-from 4,083 (2001/2) to 15,870 (2016/17). I argue that understanding on a provincial scale how many FISs are also ELLs - that is, the number of students falling into the Pateo School District's ELL-International category-would illustrate a very different picture of ELL increases over the last decade, and may give a greater sense of urgency to the BCTF's (2017) reported decreases in ELL specialist teachers. If numbers were calculated based on the lowest percentage reported by the Pateo School District (i.e., $58 \%$, Table 2), for instance, the current number of ELLs in the province would increase by over 9,000 students (from 62,801 to over 72,006). Given that at present $100 \%$ of FIS tuition revenue in $\mathrm{BC}$ is collected, managed, and distributed by school districts, and that there is little transparency about how (or whether) these funds are allocated specifically for EAL learning and/or teaching at the district or school level (Kuehn, 2014), broader understanding of the connections between FISs and EAL education is needed. Such an understanding would be relevant to FISs, who have been recruited with the promise of access to quality education and a $\mathrm{BC}$ high school credential, but may not be receiving the specialized ELL funding they require in order to realize that promise. It is equally relevant to domestic ELLs, whose classes, learning conditions, and public education-as demonstrated by Ms. Jay and Mr. Whee's classes - are impacted by the recruitment and presence of FISs. This understanding is also relevant for teachers, who may not be fully aware of the implications of FIS presence for their ability to construct and maintain equity for all students in their classrooms. Finally, it is relevant to the public, who have been misled about the overall number of ELLs in the K-12 system.

Notwithstanding the necessary social justice orientation of policy research that has framed FIS impact primarily in terms of the economic disparities resulting from school districts' competition for FIS tuition revenues (e.g., Fallon \& Poole, 2014; Poole \& Fallon, 2015), such an orientation does not take into account the superdiverse, multiscalar, and very complex nature of how or where FIS recruitment and presence plays out in the everyday workings of districts and across different levels within schools. The analyses in this paper make the case that, even if there were equitable distribution of FIS revenues to every school district in the province, clear disparities would remain in the provision and delivery of EAL education; for example, larger districts with larger numbers of provincially funded ELLs, 
with established EAL programs and services, could more easily divert FIS tuition revenue for non-EAL purposes by placing FISs in existing ELL classes.

Thus, understanding FIS impact as an EAL education issue, by representing how, why, and for whom it is an EAL issue across different levels of the public system, adds a much-needed scalar nuance to current accounts of FIS impact. More controversially, such a focus might also draw attention to some of the paradoxes relating to district- and schoollevel management and uses of specialized ELL funding and FIS revenues. As Wild et al. (2006) have pointed out:

funding for ESL services is not targeted [at the district level]; this means that school districts are not required to show how ESL funds are spent. The allocation of funds is dependent upon the knowledge base and attitudes of senior administrators and principals toward ESL learning and programs. Funds can be easily redirected to other programs with the rationale that ultimately they will benefit ESL students. (p. 3)

Wild et al.'s description mirrors the current case for FIS tuition revenues as well. Thus, not only does the ability to recruit FISs result in cross-district inequities where market-driven funding is concerned (e.g., Poole \& Fallon, 2015), an examination of how these funds are managed at the school and district levels would add an important layer of granularity to debates about education funding in BC. Should there be greater transparency about how FIS tuition fees are collected, managed, or earmarked by school districts? How might such transparency influence future stakeholder discussions with respect to the allocation of, or provincially mandated levies upon, FIS tuition revenues (see, e.g., BCMoE, 2013, 2018)?

\section{Concluding Remarks}

In this article, I have discussed some of the complex ways the presence and impact of FISs are connected to EAL education in BC's public schools. My argument is that the consistent, omnipresent, and taken-for-granted discursive and material manifestation of these FIS-EAL connections, across data from multiple sources, are demonstrative of FIS socialization of, and within, BC's public educational system.

This article does not focus on issues related to international education at the tertiary level, thus its attentiveness to K-12 contexts is itself an important contribution to applied linguistics and education-related research. Further, the article's consideration of the intersecting matters of internationalization, migration, English language learning, public schooling, and socialization draw attention to the need for work that centres on the experiences of young people negotiating their education under such circumstances (e.g., Waters, 2014, 2015). Where EAL education is concerned, the article's identification of FISs as provincially unrecognized, unaccounted for, and unfunded ELLs is important for two main reasons: the first is because the overwhelming majority of school-aged FISs in BC (and North America more broadly) are from countries where English is not the dominant language of everyday interaction or schooling (e.g., BCCIE, 2013, 2016; Citizenship and Immigration Canada, 2015; Kunin \& Associates, 2013, 2016); and the second, because there is a vast and highly established body of research that has demonstrated how ELLs are characteristically marginalized in North American schools (e.g., Ashworth, 2001; Cummins, Mirza, \& Stille, 2012; Early, 1990, 2001; Early \& 
Hooper, 2001; Early \& Marshall, 2008; Faltis \& Wolfe, 1999; Harklau, 2000, 2003, 2006; Talmy, 2005, 2008, 2009a, 2009b). Further research is needed not only to ensure "that international students [FISs] would receive the same appropriate level of [EAL] service as their BC resident peers" (BCMoE, 2013, p. 13), but also to ensure EAL education for BC residents is suitably funded and professionally supported.

Not addressed in this article, though of equal or greater importance for future studies, are investigations of the in- and out-of-school experiences of individual FISs (e.g., getting out of ESL, homestay, shadow education), the attendant socialization processes relevant in these different contexts, or how these experiences and processes might be related to EAL education in BC's K-12 public education system (and beyond). Focusing on how FISs position and make sense of FIS-EAL connections in and across these research contexts would begin to respond to Talmy's (2015) call for "more and better" research investigating "the complexities of ESL learning in superdiverse public school settings" ( $\mathrm{p}$. $365)$.

Lastly, as the analysis of the categories of Non-Residents, ELL, and ELLInternational offered in this article suggests, working toward understanding FIS presence in schools requires a multidimensional and multiscalar approach that can identify discursive shifts (da Silva \& Heller, 2009) in complex environments. On a larger scale, and following the work of Gerrard $(2015,2016)$, the same might also be inferred about understanding the internationalization of K-12 public education in BC, Canada, or other English-dominant receiving countries (i.e., Australia, New Zealand, the United Kingdom, or the United States of America): How might (marketized) K-12 public education - now socialized to include and desire, as well as to accommodate overseas demands for, FIS presence in K-12 public schools - also be experiencing its own discursive, material, and socio-spatial shifts? Is it possible, or desirable, to continue imagining public education in $\mathrm{BC}$ or Canada as a (provincially or nationally) bounded entity? Is it in our interest to conceive of K-12 public education in these English-dominant contexts as disconnected from larger global (linguistic, educational, or even economic) processes and actors from whom its privileges are relationally derived?

Correspondance should be addressed to Ryan Deschambault.

Email: ryan.deschambault@ubc.ca

\section{Acknowledgement}

This article has benefitted greatly from the input of many people. Specifically, I would like to acknowledge the anonymous CJAL * RCLA reviewers and the editorial team for substantive and helpful feedback on earlier drafts of the article, and Josée Le Bouthillier for translating the abstract into French.

\section{Notes}

${ }^{1}$ Perhaps not coincidentally, a similar effort has been mobilized by the Federal Government of Canada and can be traced through commissioned reports (i.e., Illuminate Consulting Group, 2009, 2011; Kunin \& Associates, 2009, 2012), federal level advisory reports (Foreign Affairs, Trade and Development Canada, 2012), strategy documents (Foreign 
Affairs, Trade and Development Canada, 2014), and newly articulated regulations for international students (Citizenship and Immigration Canada, 2014). These seemingly parallel policy efforts have occurred even though K-12 public education in the Canadian context is a provincial, rather than federal, responsibility.

${ }^{2}$ Each of the studies authored by Popadiuk (i.e., Popadiuk, 2009, 2010; Popadiuk \& Marshall, 2011) rely on data collected for the author's magistral thesis (Popadiuk, 1998).

${ }^{3}$ The names of all participants, personnel, the school, and the district in which the school was located are all pseudonyms.

${ }^{4}$ For a fuller description of the larger study's methodology, methods, and processes of data generation and management, please see Deschambault (2015, pp. 38-85).

${ }^{5}$ I have used China and South Korea as examples here because according to the most recent research, across all levels of schooling China and Korea are the two top source countries for international students to British Columbia (Kunin \& Associates, 2016).

${ }^{6} \mathrm{The} \mathrm{BCMoE}$ has also reported, anecdotally, that stakeholders from the K-12 International Education sector "cautioned against prescribing specific English Language Learner support levels for international students" (BCMoE, 2013, p. 13; see also, e.g., BCMoE, 2018).

${ }^{7}$ Non-Residents students are defined for statistical purposes as follows: "Students who are not ordinarily residents and whose parents/guardians are not residents of British Columbia" (BCMoE, 2016, p. 33).

${ }^{8}$ Funding eligibility might appear to be determined by a student's immigration status (i.e., whether they are Permanent Residents or Citizens of Canada). However, as I have shown elsewhere, new education policy has made this a grey area; that is, under the new policy, it possible for permanent residents and citizens of Canada to lawfully be charged FIS tuition fees at the discretion of local school districts (see Deschambault, 2015, pp. 103-123).

${ }^{9}$ I use the phrase "who participated in my study" purposefully; it is used to suggest that in each class, there were students who opted not to participate but who might also likely have been fee-paying international students. Students who opted not to participate are enumerated in Figures 2 and 3 simply as "Student."

${ }^{10}$ Double asterisks next to a student's name are used to indicate the student left the class at some point during the year. In this case, MJ left to return to Korea in February to attend high school there and Neon had returned to China in March, after administration had contacted his parents (in China) about his high level of truancy.

${ }^{11}$ A single asterisk is used to indicate that a student entered the class at some point during the year. In this case, Nita entered QHS as a new student in May. 
${ }^{12}$ Earlier in the same interview, IEP had reported that, "many of our [Pateo School District] teachers don't know which student is international and which is immigrant and which is you know been here forever or came here last year" (Deschambault, 2015, p. 157).

\section{References}

Arber, R. (2009). Discourses of antagonism and desire: Marketing for international students in neighbourhood schools. Globalisation, Societies and Education, 7(2), 167-184.

Arnott, A. G. (2012). "You can study with joy": Exploring international students' attitudes and opinions regarding their educational experiences in a Canadian secondary school (Unpublished master's thesis). University of British Columbia, Vancouver, Canada. Retrieved from https://circle.ubc.ca/bitstream/handle/2429/42321/ubc_2012_fall_arnott_amanda.pd f? sequence $=1$

Ashworth, M. (2001). ESL in British Columbia. In B. Mohan, C. Leung, \& C. Davison (Eds.), English as a second language in the mainstream: Teaching, learning and identity (pp. 93-106). New York, NY: Pearson.

Baquedano-López, P., \& Mangual Figueroa, A. (2011). Language socialization and immigration. In A. Duranti, E. Ochs, \& B. Schieffelin (Eds.), Handbook of language socialization (pp. 536-563). Malden, MA: Wiley-Blackwell.

Bartlett, L., \& Vavrus, F. (2014). Transversing the vertical case study: A methodological approach to studies of educational policy as practice. Anthropology and Education Quarterly, 45(2), 131-147.

Bill 34-2002: School Amendment Act. (2002). $3^{\text {rd }}$ Reading May 13, 2002, $37^{\text {th }}$ Parliament $3^{\text {rd }}$ session. Retrieved from https://www.leg.bc.ca/37th3rd/3rd read/gov34-3.htm

Blommaert, J., \& Rampton, B. (2011). Language and superdiversity. $\bar{D}$ iversities, $13(2), 1$ 22.

Bolden, G. (2004). The quote and beyond: Defining boundaries of reported speech in conversational Russian. Journal of Pragmatics, 36(6), 1071-1118.

British Columbia Council for International Education. (2011). International education in British Columbia: Summary of findings. Retrieved from http://www.bccie.bc.ca/sites/bccie_society/files/BCCIE_IntEdReport_SnapShot.pdf

British Columbia Council for International Education. (2013). Update on international education in British Columbia: By the numbers. Retrieved from http://www.bccie.bc.ca/sites/bccie_society/files/Update2013_IntlEd_Snapshot.pdf

British Columbia Council for International Education. (2016). Infographic: ${ }_{-}$Update on international education in $B C$ (K-12 sector). Retrieved from http://bccie.bc.ca/wp-content/uploads/2016/03/2013-14-K-12-Design_web.pdf

British Columbia Council for International Education. (2017). Infographic: Update on the economic impact of international education in BC (all sectors). Retrieved from http://bccie.bc.ca/wp-content/uploads/2017/02/Infographic-Economic-Impact-ofInternational-Education-in-BC-all-sectors-\%E2\%80\%93-2015-Update.pdf 
British Columbia Ministry of Education. (n.d.). Legislation and policy: Glossary"International students." Victoria, Canada: Government of British Columbia. Retrieved from http://www2.gov.bc.ca/gov/topic.page?id=75ED503C974346119E02DDC9F3F644 91

British Columbia Ministry of Education. (2009). English language learning: Policy and guidelines. Victoria, Canada: Government of British Columbia. Retrieved from https://www.bced.gov.bc.ca/ell//policy/guidelines.pdf

British Columbia Ministry of Education. (2010). 2009/10 Summary of key information. Victoria, Canada: Government of British Columbia. Retrieved from http://www.bced.gov.bc.ca/reporting/docs/ski.pdf

British Columbia Ministry of Education. (2013). K-12 International education regional roundtables. Victoria, Canada: Government of British Columbia. Retrieved from www.bced.gov.bc.ca/pubs/regionalroundtables.pdf

British Columbia Ministry of Education. (2016). Student statistics-2015/16: Provincepublic and independent schools combined. Victoria, Canada: Government of British Columbia. Retrieved from https://www.bced.gov.bc.ca/reports/pdfs/student_stats/prov.pdf

British Columbia Ministry of Education. (2017). Student statistics-2016/17: Provincepublic and independent schools combined. Victoria, Canada: Government of British Columbia. Retrieved from https://www.bced.gov.bc.ca/reports/pdfs/student_stats/prov.pdf

British Columbia Ministry of Education. (2018). Improving equity and accountability: Report of the funding model review panel. Victoria, Canada: Government of British Columbia. Retrieved from https://www2.gov.bc.ca/assets/gov/education/administration/resourcemanagement/k12funding/funding-model-review/independent_review_panelfinal_report_2018.pdf

British Columbia Teachers' Federation. (2012). 2012 BC education facts. Vancouver, Canada. Retrieved from http://www.bctf.ca/uploadedFiles/Public/Publications/2012EdFacts.pdf

British Columbia Teachers' Federation. (2013). Better schools for BC-The numbers tell the story. Vancouver, Canada. Retrieved from http://issuu.com/teachernewsmag/docs/2013_numbers_tell_the_storyissuu $/ 1 ? \mathrm{e}=6001376 / 1768831$

British Columbia Teachers' Federation. (2017). Education facts: Enrolling and nonenrolling teaching positions in $B C$. Vancouver, Canada. Retrieved from https://bctf.ca/uploadedFiles/Public/Publications/FactSheets/TeacherStaffing.pdf

Bronson, M. C., \& Watson-Gegeo, K. A. (2008). The critical moment: Language socialization and the (re)visioning of first and second language acquisition. In P. A. Duff \& N. H. Hornberger (Eds.), Encyclopedia of language education: Language socialization (Vol. 8, pp. 43-56). New York, NY: Springer.

Canadian Bureau for International Education. (2015). A world of learning: Canada's performance and potential in international education. Retrieved from http://www.cbie.ca/about-ie/facts-and-figures/ 
Citizenship and Immigration Canada. (2014). Notice-New regulations for international students finalized. Retrieved from

http://www.cic.gc.ca/english/department/media/notices/2014-02-12.asp

Citizenship and Immigration Canada. (2015). Facts and figures 2013-Immigration overview: Temporary residents: International students with valid permit(s) in calendar year. Retrieved from http://www.cic.gc.ca/english/resources/statistics/facts2013/temporary/5-1.asp

Clark, H. H., \& Gerrig, R. J. (1990). Quotations as demonstrations. Language, 66(4), $764-805$.

Creese, A. (2008). Linguistic ethnography. In K. A. King \& N. H. Hornberger (Eds.), Encyclopedia of language and education: Research methods in language and education ( $2^{\text {nd }}$ ed., Vol. 10, pp. 229-241). New York, NY: Springer.

Cummins, J., Mirza, R., \& Stille, S. (2012). English language learners in Canadian schools: Emerging directions for school-based policies. TESL Canada Journal, 29(6), 25-48.

da Silva, E., \& Heller, M. (2009). From protector to producer: The role of the State in the discursive shift from minority rights to economic development. Language Policy, 8, 95-116.

Deschambault, R. (2014, March). ESL all the way down: Reframing fee-paying international students' impact on British Columbia's K-12 schools. Paper presented at the American Association for Applied Linguistics (AAAL) Annual Conference, Portland, OR.

Deschambault, R. (2015). Economizing education: Fee-paying ESL students in a public high school (Doctoral dissertation). University of British Columbia. Retrieved from https://open.library.ubc.ca/collections/ubctheses/24/items/1.0220586

Drew, P. (2006). When documents "speak": Documents, language, and interaction. In P. Drew, G. Raymond, \& D. Weinberg (Eds.), Talk and interaction in social research methods (pp. 63-80). London, United Kingdom: Sage.

Duff, P. (2002). The discursive co-construction of knowledge, identity, and difference: An ethnography of communication in the high school mainstream. Applied Linguistics, 23, 289-322.

Duff, P. (2008a). Case study research in applied linguistics. New York, NY: Lawrence Erlbaum.

Duff, P. (2008b). Language socialization, participation and identity: Ethnographic approaches. In M. Martin-Jones, A.-M. de Mejia, \& N. Hornberger (Eds.), Encyclopedia of language and education, Discourse and education ( $2^{\text {nd }}$ ed., Vol. 3 , pp. 107-119). New York, NY: Springer.

Duff, P. (2012). Second language socialization. In A. Duranti, E. Ochs, \& B. Schieffelin (Eds.), Handbook of language socialization (pp. 564-586). New York, NY: Blackwell.

Duff, P. (2014). Case study research on language learning and use. Annual Review of Applied Linguistics, 34, 233-255. doi:10.1017/S0267190514000051

Duff, P. (2015). Transnationalism, multilingualism, and identity. Annual Review of Applied Linguistics, 35, 1-24. doi:10.1017/S026719051400018X

Duff, P., \& Hornberger, N. H. (Eds.). (2008). Encyclopedia of language and education, Language socialization ( $2^{\text {nd }}$ ed., Vol. 8). Boston, MA: Springer. 
Duff, P., \& Talmy, S. (2011). Language socialization approaches to second language acquisition: Social, cultural, and linguistic development in additional languages. In D. Atkinson (Ed.), Alternative approaches to SLA (pp. 95-116) London, United Kingdom: Routledge.

Early, M. (1990). Enabling first and second language learners in the classroom. Language Arts, 67(6), 567-575.

Early, M. (2001). Language and content in social practice: A case study. Canadian Modern Language Review, 58(1), 156-179.

Early, M., \& Hooper, H. (2001). Implementation of the Vancouver School Board's ESL initiatives. In B. Mohan, C. Leung, \& C. Davison (Eds.), English as a second language in the mainstream (pp. 138-150). New York, NY: Longman/Pearson.

Early, M., \& Marshall, S. (2008). Adolescent ESL students' interpretation and appreciation of literary texts: A case study of multimodality. Canadian Modern Language Review, 64(3), 377-397.

Fallon, G., \& Pancucci, S. (2003). Reframing public educational services and programs as tradable commodities-A synthesis and critique of British Columbia's Bill 34. Brock Education, 13(1), 50-60.

Fallon, G., \& Paquette, G. (2009). Introducing a market element into the funding mechanism of public education in British Columbia: A critical policy analysis of the School Amendment Act, 2002. McGill Journal of Education, 44(2), 143-162.

Fallon, G., \& Poole, W. (2014). The emergence of a market-driven funding mechanism in K-12 education in British Columbia: Creeping privatization and the eclipse of equity. Journal of Education Policy, 29(3), 302-322. doi:10.1080/02680939.2013.820354

Faltis, C. J., \& Wolfe, P. M. (Eds.). (1999). So much to say: Adolescents, bilingualism, and ESL in the secondary school. New York, NY: Teachers College Press.

Farrugia, C.A. (2014, July). Charting new pathways to higher education: International secondary students in the United States. Institute of International Education (Center for Academic Mobility Research). New York: USA. Retrieved from http://www.iie.org/ /media/Files/Corporate/Publications/IIE-InternationalSecondary-Students-In-The-US.ashx?la=en

Findlay, A. (2011, January 19). Local school boards offsetting financial shortfalls by recruiting foreign students. Straight.com. Retrieved from http://www.straight.com

Findlay, A. (2013, February 4). Paying for public school. BC Business. Retrieved from http://www.bcbusiness.ca

Foreign Affairs, Trade and Development Canada. (2012). International education: A key driver of Canada's future prosperity. Retrieved from http://www.international.gc.ca/education/assets/pdfs/ies_report_rapport_sei-eng.pdf

Foreign Affairs, Trade and Development Canada. (2014). Canada's international education strategy: Harnessing our knowledge advantage to drive innovation and prosperity. Retrieved from http://international.gc.ca/global-markets-marches mondiaux/assets/pdfs/overview-apercu-eng.pdf

Gerrard, J. (2015). Public education in neoliberal times: Memory and desire. Journal of Education Policy, 30(6), 855-868. doi:10.1080/02680939.2015.1044568

Gerrard, J. (2016). Whose public, which public? The challenge for public education. Critical Studies in Education, 1-14. doi:10.1080/17508487.2016.1186711 
Goodnough, A. (2010, October 26). Needing students, Maine school hunts in China. The New York Times (Online). Retrieved from http://www.nytimes.com

Government of British Columbia. (2012a). British Columbia's international education strategy. Retrieved from

http://www.aved.gov.bc.ca/internationaleducation/forms/InternationalEducationStra tegy_WEB.PDF

Government of British Columbia. (2012b). Canada starts here: The BC jobs plan. Retrieved from http://www.bcjobsplan.ca/wp-content/uploads/BC-Jobs-PlanPDF.pdf

Gunderson, L. (2007). A review of ESL services in the Abbotsford school board. Commissioned by the Trustees of the Abbotsford School Board. Retrieved from http://lled.educ.ubc.ca/sites/lled.educ.ubc.ca/files/pdf/abbotsfordreview.pdf

Harklau, L. (2000). From the "good kids" to the "worst": Representations of English language learners across educational settings. TESOL Quarterly, 34, 35-67.

Harklau, L. (2003). Representational practices and multimodal communication in US high schools: Implications for adolescent immigrants. In R. Bayley \& S. R. Schecter (Eds.), Language socialization in bilingual and multilingual societies (pp. 83-97). Clevedon, United Kingdom: Multilingual Matters.

Harklau, L. (2006). The adolescent English language learner: Identities lost and found. In J. Cummins \& C. Davison (Eds.), International handbook of English language education (pp. 639-653). Norwell, MA: Springer.

Holt, E. (2007). 'I'm eyeing your chop up mind': Reporting and enacting. In E. Holt \& R. Clift (Eds.), Reporting talk: Reported speech in interaction (pp. 47-80). Cambridge, United Kingdom: Cambridge University Press.

Hopkins, K. (2012, May 11). 4 benefits for international students at U.S. high schools: An introduction to American life and culture before college can help. USNews. Retrieved from http://www.usnews.com

Illuminate Consulting Group. (2009). Best practices on managing the delivery of Canadian education marketing. A report commissioned by the Department of Foreign Affairs and International Trade Canada. Retrieved from http://www.international.gc.ca/education/assets/pdfs/best_practicespratiques_exemplaires_eng.pdf

Illuminate Consulting Group. (2011). Canada's capacity for international student enrollment. A report commissioned by Foreign Affairs and International Trade Canada. Retrieved from http://www.international.gc.ca/education/capacity_reportrapport_sur_les_capacites.aspx

Kuehn, L. (2002, Nov/Dec). B.C. Liberals push boards to market education. Teacher Newsmagazine, 16(2). Retrieved from https://www.bctf.ca/publications/NewsmagArticle.aspx?id=9860

Kuehn, L. (2007). BC international student revenue and FTE enrolment, 2001-02 to 200506. British Columbia Teachers' Federation Research Report (2007-EF-01). Retrieved from http://bctf.ca/uploadedFiles/Publications/Research_reports/2007ef01.pdf

Kuehn, L. (2012a). BC international student revenue grows again. British Columbia Teachers' Federation Research Report (2012-EF-02). Retrieved from http://bctf.ca/uploadedFiles/Public/Publications/ResearchReports/2012-EF02_BC_international_student_revenue_grows_again $\% 5 \mathrm{~B} 1 \% 5 \mathrm{D} . \mathrm{pdf}$ 
Kuehn, L. (2012b). International students in BC, 2011-12. British Columbia Teachers' Federation Research Report (2012-EF-03). Retrieved from http://bctf.ca/uploadedFiles/Public/Publications/ResearchReports/2012-EF-03.pdf

Kuehn, L. (2014). International students in BC, 2012-13. British Columbia Teachers' Federation Research Report (RR2014-01). Retrieved from www.bctf.ca/uploadedFiles/Public/.../ResearchReports/RR2014-01.pdf

Kuehn, L. (2018). International student tuition income increases - and inequality grows. British Columbia Teachers' Federation Research Report. Retrieved from https://bctf.ca/uploadedFiles/Public/Publications/ResearchReports/2018-0813/report.pdf

Kunin, R., \& Associates. (2009). Economic impact of international education in Canada. A report commissioned by Foreign Affairs and International Trade Canada. Retrieved from http://www.international.gc.ca/education/assets/pdfs/RKA_IntEd_Report_eng.pdf

Kunin, R., \& Associates. (2011). Economic impact of international education in British Columbia. A report commissioned by the British Columbia Council for International Education. Retrieved from http://www.bccie.bc.ca/sites/bccie_society/files/BCCIE_IntEdReport_110221.pdf

Kunin, R., \& Associates. (2012). Economic impact of international education in CanadaAn update. A report commissioned by Foreign Affairs and International Trade Canada. Retrieved from http://www.international.gc.ca/education/assets/pdfs/economic_impact_en.pdf

Kunin, R., \& Associates. (2013). An update on the economic impact of international education in British Columbia. A report commissioned by the British Columbia Council for International Education. Retrieved from http://www.bccie.bc.ca/sites/bccie_society/files/Kunin\%20Report\%202013(Web).p df

Kunin, R., \& Associates. (2016). An update on the economic impact of international education in British Columbia. A report commissioned by the British Columbia Council for International Education. Retrieved from http://www.bccie.bc.ca/wpcontent/uploads/2016/02/Kunin-Report-2016.pdf

Kunin, R., \& Associates. (2017). An assessment of the economic impact of international education in British Columbia in 2010 and 2015: Final report. A report commissioned by the British Columbia Council for International Education. Retrieved from http://bccie.bc.ca/wp-content/uploads/2017/02/RKA-Internationaleducation-Rpt-to-BCCIE-final-revised-1.pdf

Lewis, N. (2005). Code of practice for the pastoral care of international students: Making a globalising industry in New Zealand. Globalisation, Societies and Education, 3(1), $5-47$.

Leve, A. M. (2011). Constructing the 'Study in Australia'TM experience': Full fee-paying overseas students in state government schools $\sim$ a small but integral player $\sim$ (Doctoral dissertation). Retrieved from http://www.researchgate.net/publication/271270916_Constructing_the_\%27Study_i n_Australia_experience\%27_Full_fee_paying_overseas_students_in_state_governm ent_schools_a_small_but_integral_player 
Lo, A., Abelmann, N., Kwon, S. A., \& Okazaki, S. (Eds.). (2014). South Korea's education exodus: The life and times of early study abroad. Seattle, WA: University of Washington Press.

Li, W., \& Thomas, M. (2016, April 29). Saanich school board says it won't balance its budget. CBCNews. Retrieved from http://www.cbc.ca/news/canada/britishcolumbia/saanich-school-board-says-it-won-t-balance-its-budget-1.3559008

Marklein, M. B. (2015, May 23). Foreign students take high school route to university. University World News, 368. Retrieved from http://www.universityworldnews.com

Matthews, J. (2002). International education and internationalisation are not the same as globalisation: Emerging issues for secondary schools. Journal of Studies in International Education, 6(4), 369-390. doi:10.1177/102831502237642

Matthews, J., \& Sidhu, R. (2005). Desperately seeking the global subject: International education, citizenship and cosmopolitanism. Globalisation, Societies and Education, 3(1), 49-66. doi:10.1080/14767720500046179

Melnychuk, P. (2016, April 26). Maple Ridge school board, MLA in war of words over funding. Maple Ridge News. Retrieved from http://www.mapleridgenews.com/news/377148661.html

Mitchell, A. (2004, September 7). Canada's public schools attract foreign families willing to pay dearly. The Globe and Mail. Retrieved from http://license.icopyright.net/user/viewFreeUse.act?fuid=MTE0NzgxNzY\%3D

Nelson, J. (2013). What is the impact of international transition on social and emotional health? A case study of East Asian international students in the Coquitlam school district (Master's graduating paper). Retrieved from http://summit.sfu.ca/system/files/iritems1/13193/Nelson-MEd.pdf

Nuwer, R. (2014, July 10). In U.S. high schools, full-time international students now outnumber exchange students. Smithsonian.com. Retrieved from http://www.smithsonianmag.com

Ochs, E. (1986). Introduction. In B. B. Schieffelin \& E. Ochs (Eds.), Language socialization across cultures (pp. 1-13). New York, NY: Cambridge University Press.

Park, J. S.-Y., \& Bae, S. (2009). Language ideologies in educational migration: Korean jogi yuhak families in Singapore. Linguistics and Education, 20(4), 366-377. doi:10.1016/j.linged.2009.09.001

Park, J. S.-Y., \& Lo, A. (Eds.). (2012a). Globalization, multilingualism, and identity in transnational perspective: The case of South Korea [Special issue]. Journal of Sociolinguistics, 16(2).

Park, J. S.-Y., \& Lo, A. (2012b). Transnational South Korea as a site for a sociolinguistics of globalization: Markets, timescales, neoliberalism. Journal of Sociolinguistics, 16(2), 147-164. doi:10.1111/j.14679841.2011.00524.x

Park, J. S.-Y., \& Wee, L. (2012). Markets of English: Linguistic capital and language policy in a globalizing world. New York, NY: Routledge.

Pawson, C. (2016, April 24). Halt development for sake of education, says Surrey trustee Laurae McNally. CBCNews. Retrieved from http://www.cbc.ca/news/canada/british-columbia/halt-development-for-sake-ofeducation-says-trustee-laurae-mcnally-1.3551179 
Popadiuk, N. (1998). The adjustment of international secondary students in the Vancouver School District (Master's thesis). Retrieved from http://elk.library.ubc.ca/bitstream/handle/2429/8211/ubc_1998-0580.pdf

Popadiuk, N. (2009). Unaccompanied Asian secondary students studying in Canada. International Journal for the Advancement of Counselling, 31(4), 229-243. doi:10.1007/s10447-009-9080-6

Popadiuk, N. (2010). Asian international student transition to high school in Canada. The Qualitative Report, 15(6), 1523-1529.

Popadiuk, N., \& Marshall, S. (2011). East Asian international student experiences as learners of English as an additional language: Implications for school counsellors. Canadian Journal of Counselling and Psychotherapy, 45(3), 220-239.

Poole, W., \& Fallon, G. (2015). The emerging fourth tier in K-12 education finance in BC: An equity and social justice policy study. Globalisation, Societies, and Education, 13(3), 339-368. doi:10.1080/14767724.2014.996857

Potter, J., \& Hepburn, A. (2008). Discursive constructionism. In J. A. Holstein \& J. F. Gubrium (Eds.), Handbook of constructionist research (pp. 275-293). New York, NY: Guilford Press.

Qian, Y. (2012). Social spaces, symbolic power and language identities: A case study of the language use of Chinese adolescents in Canada (Doctoral dissertation). Retrieved from https://tspace.library.utoronto.ca/bitstream/1807/34855/1/Qian_Yamin_201210_Ph D_thesis.pdf

Rampton, B., Tusting, K., Maybin, J., Barwell, R., Creese, A., \& Lytra, V. (2004). UK linguistic ethnography: A discussion paper. Retrieved from www.lingethnog.org.uk.

Robertson, S. (2013). Transnational student migrants and the state: The educationmigration nexus. New York, NY: Palgrave Macmillan.

Rymes, B. (2008). Language socialization and the linguistic anthropology of education. In P. Duff \& N. H. Hornberger (Eds.), Encyclopedia of language and education: Language socialization (Vol. 8, pp. 29-42). New York, NY: Springer.

Sambides Jr., N. (2013, February 12). Maine public schools face 'competitive disadvantage' in recruiting Asians. Bangor Daily News. Retrieved from http://bangordailynews.com

Schieffelin, B. B., \& Ochs, E. (1986). Language socialization. Annual Review of Anthropology, 15, 163-191.

Shin, H. (2010). "Gireogi gajok": Transnationalism and language learning (Doctoral dissertation). Retrieved from https://tspace.library.utoronto.ca/handle/1807/19133

Study in BC. (2015). Tuition and other costs: Average cost of living for an international student in BC. Retrieved from http://studyinbc.com/costs/tuition-and-other-costs/

Talmy, S. (2005). Lifers and FOBs, rocks and resistance: Generation 1.5, identity, and the cultural productions of ESL in a high school (Doctoral dissertation). Retrieved from http://scholarspace.manoa.hawaii.edu/handle/10125/11948

Talmy, S. (2008). The cultural productions of the ESL student at Tradewinds High: Contingency, multidirectionality, and identity in L2 socialization. Applied Linguistics, 29(4), 619-644.

Talmy, S. (2009a). "A very important lesson": Respect and the socialization of order(s) in high school ESL. Linguistics and Education, 20, 235-253. 
Talmy, S. (2009b). Forever FOB?: Resisting and reproducing the Other in high school ESL. In A. Reyes \& A. Lo (Eds.), Beyond yellow English: Toward a linguistic anthropology of Asian Pacific America (pp. 347-365). New York, NY: Oxford University Press.

Talmy, S. (2010a). Critical research in applied linguistics. In B. Paltridge \& A. Phakiti (Eds.), Continuum companion to research methods in applied linguistics (pp. 127142). London, United Kingdom: Continuum.

Talmy, S. (2010b). Qualitative interviews in applied linguistics: From research instrument to social practice. Annual Review of Applied Linguistics, 30, 128-148.

Talmy, S. (2012). Second language socialization. Routledge encyclopedia of second language acquisition (pp. 571-575). New York, NY: Routledge.

Talmy, S. (2015). A language socialization perspective on identity work of ESL youth in a superdiverse high school classroom. In N. Markee (Ed.), The handbook of classroom discourse and interaction (pp. 353-368). New York, NY: John Wiley \& Sons.

Tang, D. (2014, August 14). Chinese teens seek freedom and a competitive edge at U.S. high schools. The Japan Times. Retrieved from http://www.japantimes.co.jp

Toppo, G. (2014, February 24). Public schools recruiting international high schoolers. USA Today. Retrieved from http://usat.ly/1bzsB86

Vertovec, S. (2007) Super-diversity and its implications. Ethnic and Racial Studies, 30, 1024-1054.

Waters, J. L. (2014). Dysfunctional mobilities: International education and the chaos of movement. In J. Wyn \& H. Cahill (Eds.), Handbook of children and youth studies (pp. 679-688). Singapore: Springer. doi:10.1007/978-981-4451-96-3_26-1

Waters, J. L. (2015). Educational imperatives and the compulsion for credentials: Family migration and children's education in East Asia. Children's Geographies, 13(3), 280-293. doi:10.1080/14733285.2015.972646

Weiss, E. (2014, April 3). Can international students save U.S. public schools? The New Yorker. Retrieved from http://www.newyorker.com

White, M. (2011). Budget update: Budget 2011 not enough to resolve funding crisis. British Columbia Teachers' Federation Research report (2011-EF-02). Vancouver, Canada: British Columbia Teacher's Federation. Retrieved from http://www.bctf.ca/uploadedFiles/Public/Publications/ResearchReports/2011-EF$02(1) \cdot \mathrm{pdf}$

White, M. (2012). 2012-13 Operating Grants-Too little to offset district budget shortfalls. British Columbia Teachers' Federation Research report (2012-EF-01). Vancouver, Canada: British Columbia Teacher's Federation. Retrieved from http://www.bctf.ca/uploadedFiles/Publications/Research_reports/2012-EF-01.pdf

Wild, J., Helmer, S., Tanaka, P., \& Dean, S. (2006). A “crisis in ESL education” in BC schools. A report prepared by members of the ELL Provincial Specialist Association. Retrieved from http://ellpsa.ca/wp-content/uploads/2012/01/A-Crisisin-ESL-Education-2006.pdf

Willinsky, J. (2001). After literacy: Essays. New York, NY: Peter Lang Publishers. Wortham, S. (2005). Socialization beyond the speech event. Journal of Linguistic Anthropology, 15(1), 95-112. 
Wortham, S. (2008). Linguistic anthropology of education. In M. Martin-Jones, A.-M. de Mejía, \& N. Hornberger (Eds.), Encyclopedia of language and education, Discourse and education ( $2^{\text {nd }}$ ed., Vol. 3, pp. 93-103). New York, NY: Springer.

Zeidler, M. (2016, April 28). VSB votes against proposed budget. CBCNews. Retrieved from http://www.cbc.ca/news/canada/british-columbia/vsb-budget-vote-results1.3558469

Zheng, S. (2014). Academic achievement, school engagement, and well-being of international/visa students in the Toronto District School Board's secondary schools. Toronto District School Board research report (No. 13/14-09). Retrieved from

http://www.tdsb.on.ca/LinkClick.aspx?fileticket=T6vVt4Fq_SI\%3d\&amp;tabid=41 5\&amp;portalid=0\&amp;mid $=2573$ 